\title{
A Caribou Decline Foreshadowed by Inuit in the Central Canadian Arctic: A Retrospective Analysis
}

\author{
Andrea N. Hanke, ${ }^{1,2}$ Monica Angohiatok, ${ }^{3}$ Lisa-Marie Leclerc, ${ }^{4}$ Cindy Adams ${ }^{5}$ and Susan Kutz ${ }^{1}$
}

(Received 30 September 2020; accepted in revised form 14 May 2021)

\begin{abstract}
The Dolphin and Union (DU) caribou herd (Rangifer tarandus groenlandicus $x$ pearyi), locally referred to as Island caribou, is a unique and at-risk ecotype of caribou that ranges on Victoria Island and the adjacent mainland in the central Canadian Arctic. To facilitate the incorporation of traditional knowledge (TK) and better inform the required species recovery plan, we analyzed an archived set of TK interviews done in Ekaluktutiak and Kugluktuk, Nunavut, in 2003. The overarching theme throughout the interviews was that the DU caribou were dynamic, constantly adapting to the changing environment around them. Accounts provided previously unexplored connections between temporal and spatial trends in DU caribou distribution, population, ecology, and disease syndromes. Findings of fewer animals, range shift, and increased observations of disease in the late 1990s and early 2000s suggest that early signs of the declines that have resulted in the herd being reassessed as endangered today were already apparent to Kugluktukmiut in 2003. In contrast, Ekaluktutiakmiut were seeing a stable population. Shifts in caribou range and consequently harvesting ranges were described by both communities, but more evident in Kugluktuk. When combined, the differing accounts of the two communities provided a deeper understanding of caribou ecology and trends across seasons, years, and a broad spatial range. Community differences demonstrate the cruciality of considering unique place-based perspectives and the importance of mobilizing TK from communities and knowledge keepers throughout the caribou range for a herd-level understanding. This study highlights the importance of timely analyses and reporting on TK studies to ensure a nimble conservation response in a rapidly changing environment.
\end{abstract}

Key words: archived interviews; caribou conservation; Dolphin and Union caribou; Ekaluktutiak; Kugluktuk; participatory mapping; place-based knowledge; Rangifer; traditional knowledge

RÉSUMÉ. Le troupeau de caribou (Rangifer tarandus groenlandicus x pearyi) de Dolphin-et-Union (DU), couramment appelé, dans cette région, le caribou de l'île, est un écotype de caribou unique et à risque dont l'aire de répartition s'étend sur l'île Victoria et sur la terre ferme adjacente dans le centre de l'Arctique canadien. Afin de faciliter l'intégration des connaissances traditionnelles (CT) et de mieux éclairer le plan nécessaire de rétablissement de l'espèce, nous avons analysé et archivé une série d'entrevues sur les CT réalisées en 2003 à Ekaluktutiak et à Kugluktuk, au Nunavut. Le thème principal qui est ressorti de ces entrevues était que les caribous de DU sont dynamiques et qu'ils s'adaptent continuellement à leur environnement en pleine évolution. Les descriptions obtenues par le passé n'exploraient pas les liens entre les tendances temporelles et spatiales en matière de distribution, de population, d'écologie et de syndromes de maladies caractérisant le caribou de DU. Les constatations indiquant la présence d'un moins grand nombre de bêtes, le décalage de l'aire de répartition et l'observation accrue de maladies vers la fin des années 1990 et le début des années 2000 suggèrent que les signes avant-coureurs de déclin qui ont mené à la réévaluation du troupeau, maintenant considéré comme en voie de disparition, étaient déjà visibles pour les gens de Kugluktuk en 2003. De leur côté, les gens d'Ekaluktutiak étaient témoins d'une population stable. Le décalage de l'aire de répartition du caribou et, par conséquent, des aires de récolte, a été décrit par ces deux collectivités, mais il était plus évident à Kugluktuk. Ensemble, les descriptions divergentes des deux collectivités ont permis de mieux comprendre l'écologie du caribou et les tendances le caractérisant au fil des saisons et des années, sur une vaste répartition spatiale. Les différences enregistrées dans ces collectivités attestent de la grande importance de considérer les perspectives uniques à divers lieux et l'importance de mobiliser les CT des collectivités et des gardiens du savoir à l'échelle de l'aire de répartition du caribou afin de comprendre le troupeau. Cette étude fait ressortir l'importance de produire des analyses ponctuelles et de communiquer les résultats des études des $\mathrm{CT}$ afin de donner lieu à une intervention de conservation adroite dans un environnement en évolution rapide.

\footnotetext{
${ }^{1}$ Department of Ecosystem and Public Health, Faculty of Veterinary Medicine, University of Calgary, 3280 Hospital Drive NW, Calgary, Alberta T2N 4Z6, Canada

${ }^{2}$ Corresponding author: andrea.hanke1@ucalgary.ca

${ }^{3}$ Department of Environment, Government of Nunavut, Ekaluktutiak, Nunavut X0B 0C0, Canada

${ }^{4}$ Department of Environment, Government of Nunavut, PO Box 377, Kugluktuk, Nunavut X0B 0E0, Canada

${ }^{5}$ Clinical \& Diagnostic Sciences, Faculty of Veterinary Medicine, University of Calgary, 3280 Hospital Drive NW, Calgary, Alberta T2N 4Z6, Canada

(C) The Arctic Institute of North America
} 
Mots clés: entrevues archivées; conservation du caribou; caribou de Dolphin-et-Union; Ekaluktutiak; Kugluktuk; cartographie participative; connaissances en fonction des lieux; Rangifer; connaissances traditionnelles

Traduit pour la revue Arctic par Nicole Giguère.

\section{INTRODUCTION}

Across Inuit Nunangat, the Inuit homelands in what is now called Canada, caribou (Rangifer tarandus) play central roles in ecosystem processes (Katz, 2010; Bernes et al., 2015), economic activity, food security, social engagement (Chiu et al., 2016), and Inuit ways of life (Ljubicic et al., 2018; Tomaselli et al., 2018a, b). Indeed, relationships between people and other living beings, including caribou, are often central to explanations of Inuit Qaujimajatuqangit - Inuit knowledge or Inuit philosophy (Thorpe et al., 2001; Tester and Irniq, 2008; Tagalik, 2012). Caribou populations have declined across much of their range despite their importance, bringing hardships to Inuit communities. Since 2014, the Committee on the Status of Endangered Wildlife in Canada (COSEWIC) has assessed six endangered, three threatened, and two special concern caribou designatable units, defined as "discrete and evolutionarily significant units of the taxonomic species" (COSEWIC, 2011:14; 2014a, b, 2015a, 2016, 2017a, b).

The Dolphin and Union (DU) caribou herd (Rangifer tarandus groenlandicus $x$ pearyi) refers to a migratory herd in the central Canadian Arctic. This herd characteristically summers on Victoria Island and winters on the adjacent mainland, migrating across the sea ice between these locations (ECCC, 2018). The dispersed calving behaviour of the DU caribou and the vastness of Victoria Island make the conventional ground survey methodology used for calving barren-ground caribou ineffective for monitoring the population of DU caribou (Gunn and Fournier, 2000; Nishi and Buckland, 2000). Standardized coastal stratifiedstrip aerial surveys done since 1997 indicate that the herd has declined from an estimate of 34,558 animals $(95 \%$ $\mathrm{CI}=27,757$ to 41,$359 ; \mathrm{CV}=12 \%$ ) in 1997 (Nishi and Gunn, 2004; Dumond and Lee, 2013) to 4105 animals $(95 \% \mathrm{CI}=$ 2931 to $5750 ; \mathrm{CV}=17 \%$ ) in 2018 (Leclerc and Boulanger, 2020). In 2020, a modified version of the coastal stratifiedstrip survey was done in response to community concerns and management needs. Designed with substantial community input, this survey estimated a total of 3815 animals $(95 \% \mathrm{CI}=2930$ to $4966, \mathrm{CV}=13 \%)$, a result not significantly different from the 2018 survey (Campbell et al., 2021).

Since the first population estimate in 1997, the conservation status of the DU caribou herd has changed alongside the decreasing abundance estimates. COSEWIC (2004) assessed the herd as special concern in 2004 because of the uncertainty in population abundance and concerns around harvest rates and sea ice stability. This status was adopted by the Species at Risk Act in 2011 (Government of Canada, 2011). COSEWIC (2017b) reassessed the herd as endangered in 2017 because of abundance declines and the presence of multiple threats, including reduced connectivity between summer and winter ranges (sea ice change), climate change, and unknown harvesting rates.

The Nunavut Land Claim Agreement and the Inuvialuit Final Agreement in the Northwest Territories mandate that traditional knowledge (TK) is included in conservation assessments and other management actions (INAC, 1984, 1993). Responding to this legal requirement, we revisited and analyzed a set of TK interviews on DU caribou from 2003. These interviews were done in 2003 by the Government of Nunavut to explore trends in DU caribou abundance, spatial and temporal migration, and body condition. However, analysis and reporting of the interviews was not completed because of a staffing shortage at the Government of Nunavut. The objectives of our research were to analyze the 2003 TK interviews and make them available to the DU caribou co-management partners.

\section{METHODS}

\section{Study Approach}

In this paper, we recognized TK and Western knowledge as distinct ways of knowing that include valuable and unique information about the environment (Bartlett et al., 2012; Mantyka-Pringle et al., 2017). TK is closely associated with place, so we use Ekaluktutiakmiut and Kugluktukmiut knowledge to refer to knowledge that is developed and held by the people of Ekaluktutiak and Kugluktuk (the suffix-miut in Inuinnaqtun translates to "people of"). Furthermore, our terms for TK within the Kitikmeot region were agreed upon during discussions with Kugluktukmiut in 2020. We approached this study in keeping with Elder Aupilarjuk's words "taakkua katikpanik sannginiqarniqsauqquu'mijugut," translating to "if both ways were brought together we would possibly have more strength" (McGrath, 2019), by using qualitative methods to access, organize, and understand Ekaluktutiakmiut and Kugluktukmiut knowledge. We were guided by critical realism, a research approach that allowed us to focus on and question the interpretations and relationships conveyed by the TK keepers (TKKs) and held by the authors (Maxwell and Mittapalli, 2011). The use of critical realism helped to navigate the differences between Indigenous and Western ways of knowing (see Kourantidou et al., 2020).

In this type of qualitative research, the results reflect who researchers are (Braun and Clarke, 2013; Tilley, 2016). As such, it is impossible to create objective accounts because the researchers are part of the research and are in relationship with the research and TKKs. It is possible that another set of researchers could use the same research 
process and develop different results, and a different study design would further increase the likelihood that results would differ. Because of this, the results presented below are not exhaustive and are limited to the study design and experience of the TKKs and study team (Tilley, 2016). We have detailed our methods (Armitage and Kilburn, 2015), including collaborative authorship and community input (Loseto et al., 2020), to increase the transparency and trustworthiness of the results (Tilley, 2016).

The 2003 interview design and facilitation were led by M. Angohiatok (Government of Nunavut), and the interview translation and audio-recording transcription were done by Ida Kapakatoak (Government of Nunavut), two local Inuit residents. The research team that did the data analysis was located at the University of Calgary, has an interdisciplinary background in natural and social sciences, and has well-established relationships with the Ekaluktutiak Hunters and Trappers Organization (EHTO) and the Kugluktuk Angoniatit Association (KAA). A. Hanke is the lead author and analyst. The analysis was informed by experts in caribou health (S. Kutz), caribou management (S. Kutz, L.-M. Leclerc), and social science methodologies and methods (C. Adams), with input from the EHTO, KAA, their communities, and the Government of Nunavut, Department of the Environment. The digitization of the spatial data included the lead author (A. Hanke), the Government of Nunavut, Kitikmeot regional biologist (L.- M. Leclerc), and Ashley Newman, a youth from Kugluktuk under casual employment by the Government of Nunavut.

\section{Study Area}

DU caribou are significant to the communities of Ekaluktutiak and Kugluktuk, in addition to the outpost camps of Kingauk and Uminmaktok, in Nunavut, Canada and the communities of Paulatuk and Ulukhaktok in Northwest Territories, Canada (Fig. 1) (Dumond, 2007; Tomaselli et al., 2018b; ECCC, 2018). Ekaluktutiak is located on southeastern Victoria Island and had an estimated population of 1309 in 2001 (no data for 2003) (Statistics Canada, 2016a). Kugluktuk is located on the Nunavut mainland and had an estimated population of 1212 in 2001 (no data for 2003) (Statistics Canada, 2016b).

\section{Interviews}

Before starting, the Inuk lead interviewer (M. Angohiatok) consulted the hunters and trappers' organizations in Ekaluktutiak, Kugluktuk, Kingauk, Umingmaktok, and Ulukhaktok on the study for support. Harvesters with DU caribou expertise in Ekaluktutiak and Kugluktuk were purposively selected based on the lead interviewer's personal knowledge of the communities and guidance by the hunters and trappers' organizations. Interviews were not held in the remaining communities and outpost camps. The Inuit facilitating the interviews

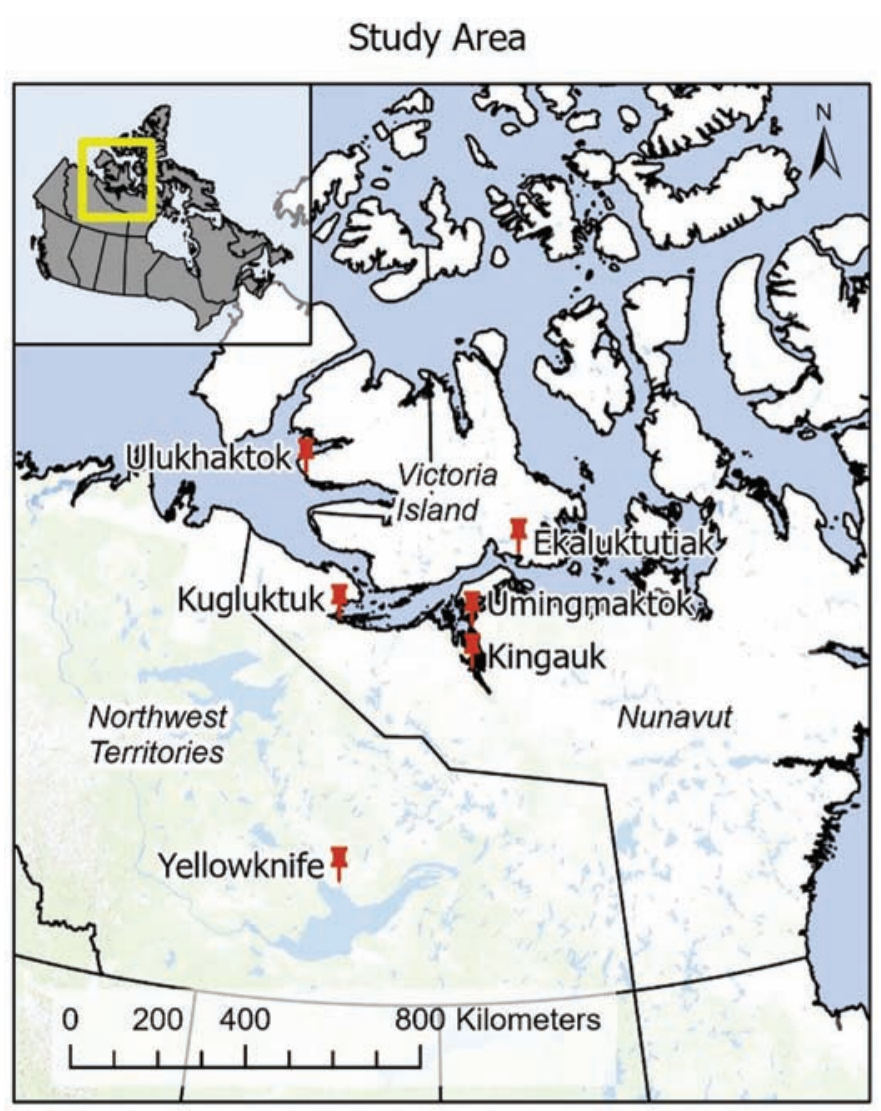

FIG. 1. Study area. Pins indicate communities.

were not trained in Western, qualitative techniques, but oral storytelling is a common form of TK transmission (McGrath, 2019). TKKs were asked structured interview questions in their preferred language (English or Inuinnaqtun) with the assistance of an interpreter. The final transcripts documented the English conversations or the English translations. TKKs were also asked to draw, on plastic map overlays, their past (pre-2003) and present (2003) harvesting grounds, seasonal locations, and migration routes pertinent to DU caribou. Although TKKs were specifically asked about DU caribou, it is possible that some TKKs' comments could, on occasion, refer to their experience with other caribou herds. However, harvesters in these communities recognize DU caribou, sometimes also called Island caribou, as distinguishable from other caribou herds by differences in size, colour, and movement patterns (Dumond, 2007; Thorpe Consulting Services, 2014).

\section{Analyses}

Analyses of the 2003 interviews occurred in 2018-20. They were informed by a preliminary report written in 2003 by M. Angohiatok as well as further consultation with her during the analysis. We followed guidelines for reflexive thematic analysis by Braun and Clarke (2006, 2021). We approached the analysis as a cyclical process of understanding the data, where we would go back and 
forth between coding and theme creation. We started by reviewing the interview transcripts in their original docx files, then we uploaded them to NVivo (qualitative data management software; Version 12) for manual coding. We coded the transcripts with two coding strategies, in vivo and holistic (Saldaña, 2016). The development of initial themes was done in Microsoft Word. We did the coding and initial theme development with the Kugluktuk-based transcripts first and the Ekaluktutiak-based transcripts second. The initial themes from both community's transcripts were refined based on manual inter-community comparison done in Microsoft Word. The refined themes were presented back during the EHTO and KAA annual general meetings in January 2019 to provide opportunities for community feedback, which was incorporated into the final themes presented in this paper.

Participatory maps were photographed, georeferenced, and digitized into polygons and polylines within ArcGIS (Ersi, Pro version 2.5.0). We followed a geoprocessing procedure detailed by Honeycutt (2012) to create density maps that show the overlaps amongst TKKs' maps and retained seasonal, temporal, and community-specific attributes in the data. We used Dissolve and Clip spatial analysis tools within ArcMap to summarize the area covered by the polygons, rounding to the nearest hundred to allow a buffer for mapping accuracy (Armitage and Kilburn, 2015; Robertson, 2017). We broadly compared these summaries to the official herd range (ECCC, 2018). We based our map symbology on defined two-point intervals with graduated colours.

\section{Ethical Considerations}

In 2003, each TKK signed a consent form, which outlined that the information would be used by the Government of Nunavut for wildlife management, related communications, and publications. In 2018, the continuation of this study was approved by the ethics review board at the University of Calgary (REB17-2427) and the Nunavut Research Institute (\#04 003 19R-M). Since the transcripts and maps were provided to us anonymized, individual quotes from the TKKs remain anonymized. We have aimed to offset this concession by maintaining open communication amongst the EHTO, KAA, Government of Nunavut, and the University of Calgary. We also presented this information at relevant community meetings, including the DU Caribou User-to-Users Working Group meetings in May 2019 and July 2020, the EHTO and Transport Canada ice-breaking meeting in September 2020 (Canadian Coast Guard, 2020), and the Government of Nunavut survey consultations in the fall of 2020 (Roberto-Charron, 2020; Campbell et al., 2021). We also prepared a report to the co-management partners in September 2020 (Hanke and Kutz, 2020).

\section{RESULTS}

Thirty people, nine older and six younger than 55 years old from Ekaluktutiak and eight older and seven younger than 55 years old from Kugluktuk were interviewed for this study. All 30 interviews were transcribed, and all 30 individual participatory maps were digitized.

\section{Participatory Maps}

The participatory maps depicted the harvesting ranges, seasonal ranges, and seasonal migration routes for DU caribou identified by the TKKs (Figs. 2-5). The final polygons $(n=408)$ denoted past $($ pre-2003) $(n=146)$ and present (2003) $(n=131)$ harvesting ranges for DU caribou, and summer $(\mathrm{n}=64)$ and winter $(\mathrm{n}=67) \mathrm{DU}$ caribou ranges. The polylines $(\mathrm{n}=524)$ denoted fall $(\mathrm{n}=265)$ and spring $(\mathrm{n}=259)$ DU caribou migration routes. The DU caribou range mapped by the TKKs represented approximately $52 \%$ of the official DU caribou range used in the management plan (ECCC, 2018). Divided by community, Ekaluktutiakmiut covered approximately $37 \%$ and Kugluktukmiut covered approximately $32 \%$ of the official range. In total, the DU caribou ranges mapped by TKKs were approximately $81 \%$ within and $19 \%$ outside of the official range (Table 1). Of the total DU caribou range mapped by the TKKs, approximately $4 \%$ mapped by Ekaluktutiakmiut and 24\% mapped by Kugluktukmiut fell outside of the official range. The Kugluktukmiut area that was outside of the official range was mostly in the southwestern part of the herd's distribution (Fig. 3).

Harvesting ranges of Ekaluktutiakmiut and Kugluktukmiut had some overlap, but those mapped by Ekaluktutiakmiut extended farther east and north and those delineated by Kugluktukmiut extended farther west and south (Fig. 2). For both communities, the present (2003) harvesting ranges for DU caribou were approximately one-third the area used in the past (pre-2003) (Table 2). The TKKs provided no explanation for why these changes occurred and didn't define a time period for the past (pre2003) harvesting.

\section{Thematic Analysis of the Interviews}

The overarching theme throughout the interviews was that caribou had dynamic realities and were constantly adapting to the changing environment around them (Fig. 6). The term realities refers to the lives and experiences of the caribou beyond that of a sole biological existence. Harvesters explained how caribou were in control of themselves, made decisions about their behaviour, and changed in response to their environment. This theme was supported by three sub-themes: "survival constraints," "the changing climate impacts," and "caribou are important for people and culture." 


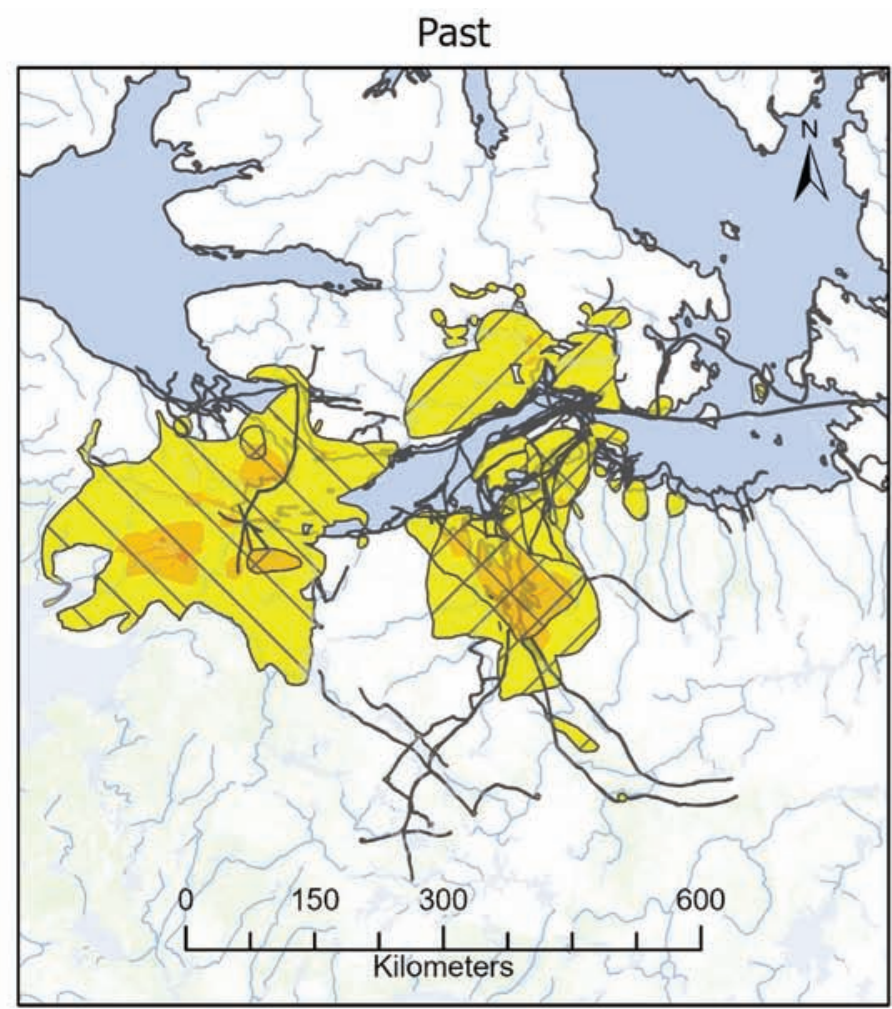

Note:

The maximum number of TKKs' maps that overlapped was 6 .

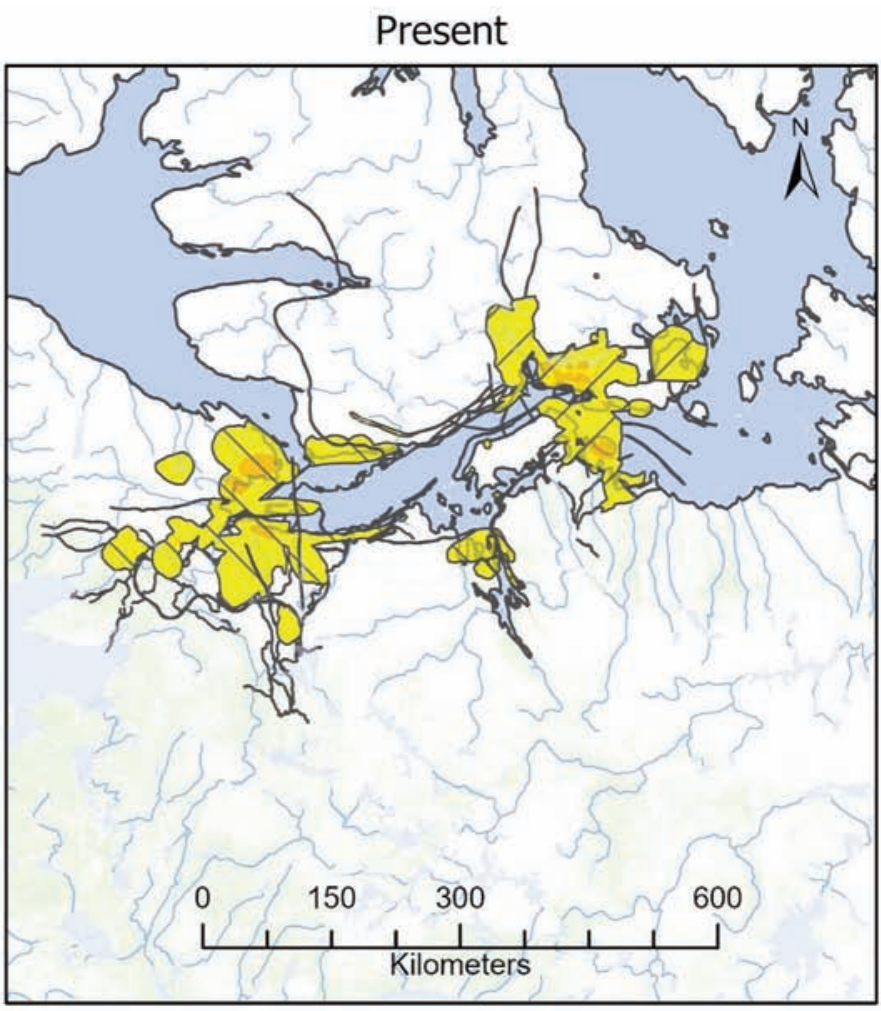

Note:

The maximum number of TKKs' maps that overlapped was 6 .

Total (Past \& Present)

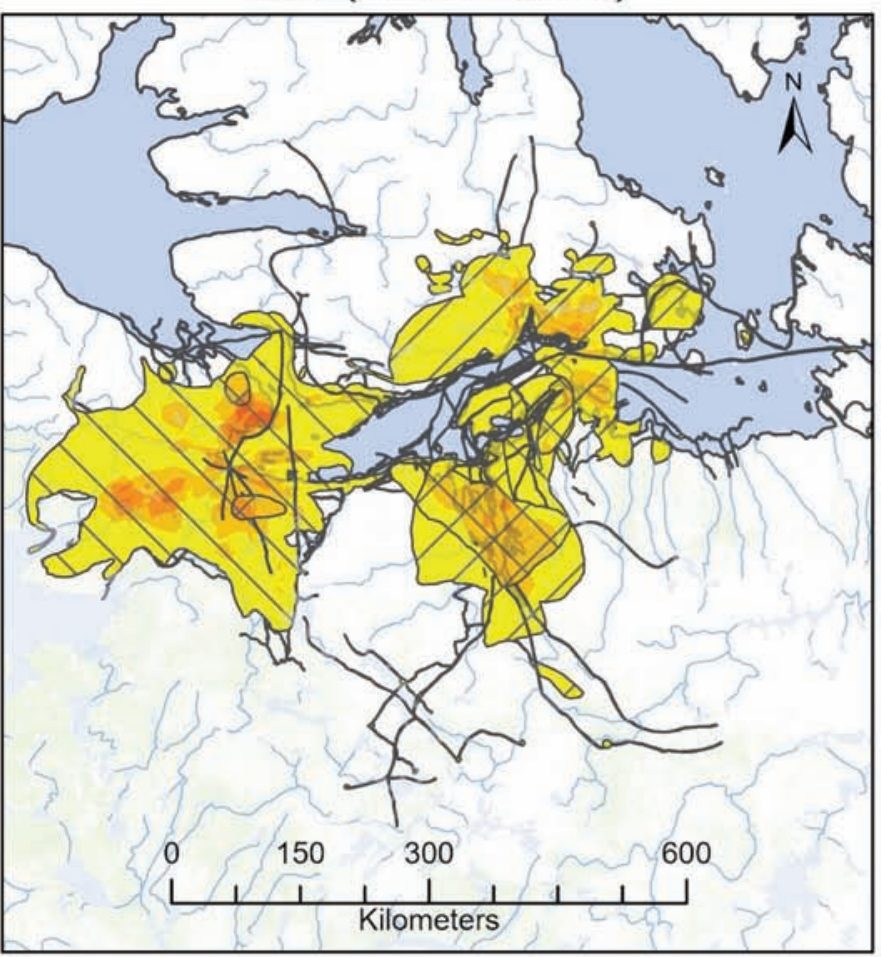

\section{Legend}

$\square$ Ekaluktutiakmiut

$\square$ Kugluktukmiut

Number of Overlapping TKKs' Maps

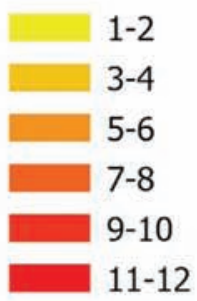

Note:

The maximum number of TKKs' maps that overlapped was 10 .

FIG. 2. Harvesting range of DU caribou as reported by Ekaluktutiakmiut (15 TKKs) and Kugluktukmiut (15 TKKs) in 2003 delimited by past range (pre-2003), present range (as reported in 2003), and the combined past and present harvesting ranges for DU caribou. Colour gradient represents the number of TKKs identifying an area as harvesting range for DU caribou. The grey lines are curved polygons that represent travel routes and are too small to show colour. 


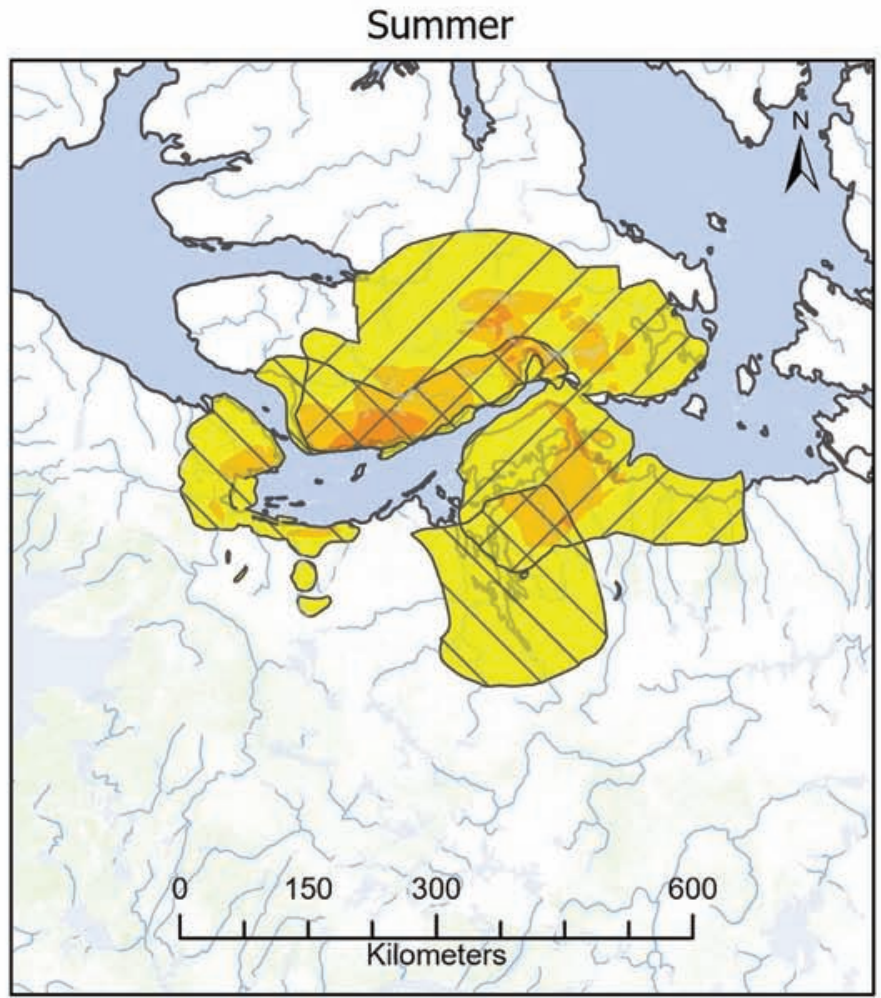

Note:

The maximum number of TKKs' maps that overlapped was 7.

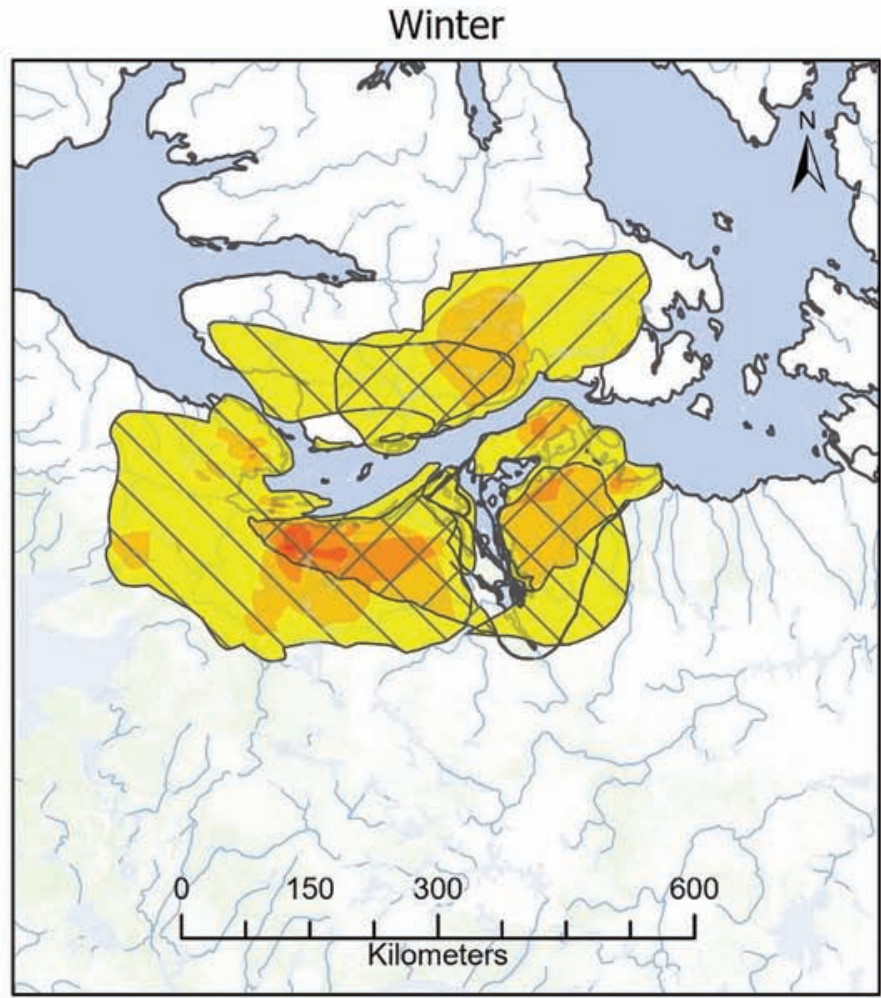

Note:

The maximum number of TKKs' maps that overlapped was 10.

\section{Total (Summer \& Winter)}

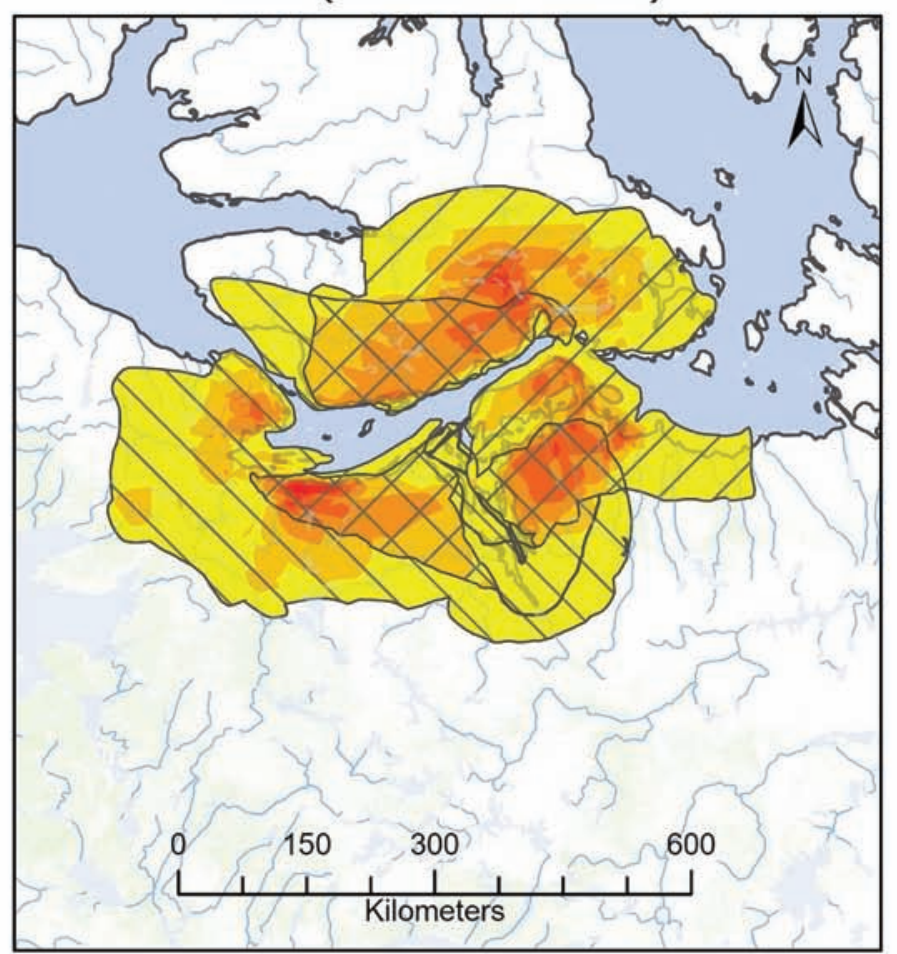

\section{Legend}

$\square$ Ekaluktutiakmiut

$\square$ Kugluktukmiut

Number of Overlapping TKKs' Maps

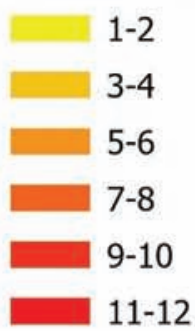

Note:

The maximum number of TKKs' maps that overlapped was 12.

FIG. 3. DU caribou range as reported by Ekaluktutiakmiut (15 TKKs) and Kugluktukmiut (15 TKKs) in 2003 delimited by summer range, winter range, and the combined summer and winter range. Colour gradient represents the number of TKKs identifying an area as DU caribou range. 
Fall

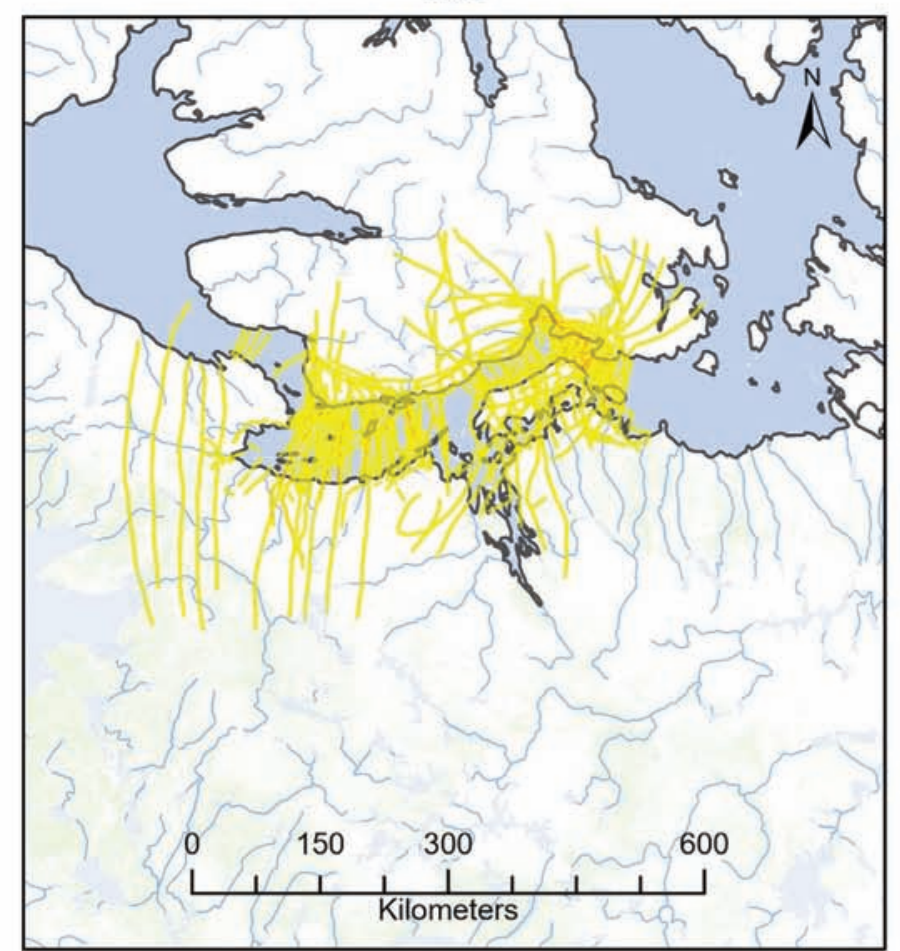

Note:

The maximum number of TKKs' maps that overlapped was 10.

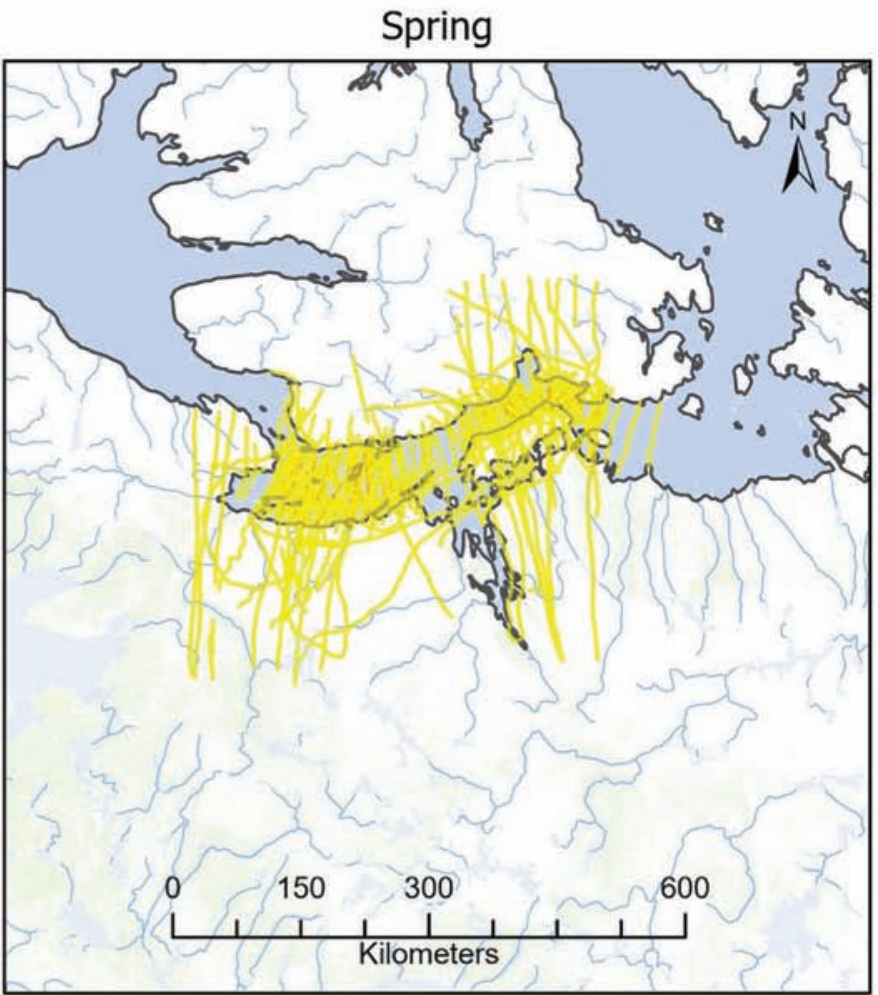

Note:

The maximum number of TKKs' maps that overlapped was 7.

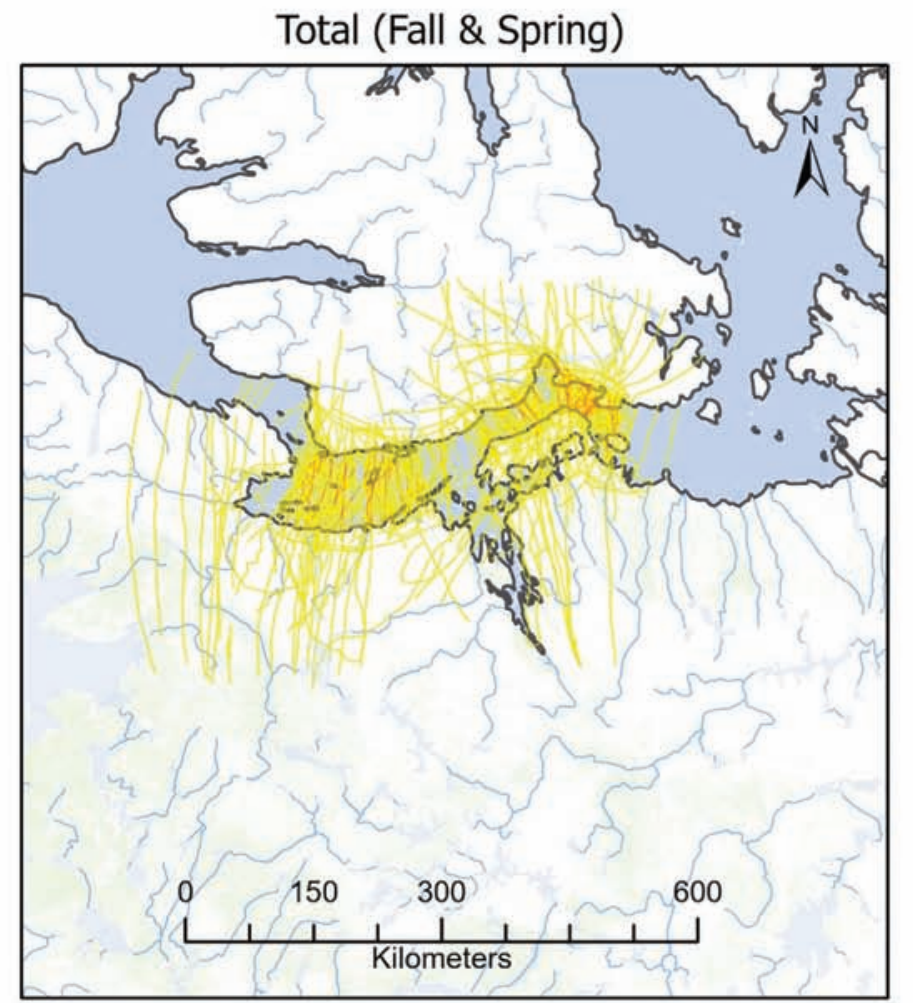

Legend

Number of Overlapping TKKs' Maps

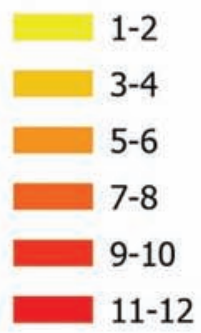

Note:

The maximum number of TKKs' maps that overlapped was 11.

FIG. 4. Migration routes of DU caribou as reported by Ekaluktutiakmiut (15 TKKs) and Kugluktukmiut (15 TKKs) in 2003 delimited by fall, spring, and the combined fall and spring routes. Colour gradient represents the number of TKKs identifying an area as a migration route. 


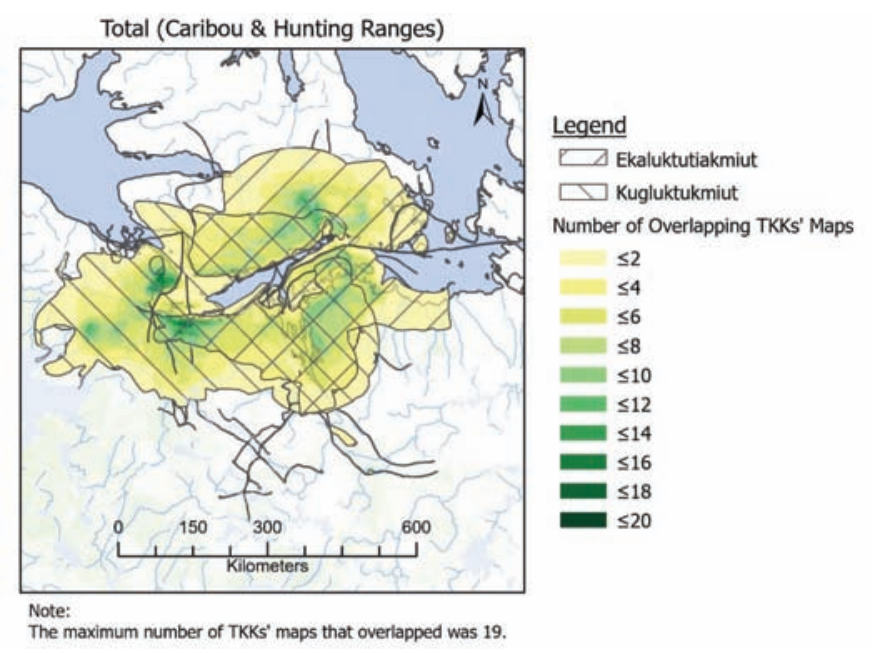

FIG. 5. Combined DU caribou range and harvesting range of DU caribou as reported by Ekaluktutiakmiut (15 TKKs) and Kugluktukmiut (15 TKKs) in 2003. Colour gradient represents the number of TKKs identifying an area as a DU caribou range or as a harvesting range for DU caribou. The dark, irregular lines are travel routes.

\section{Survival Constraints}

TKKs explained that caribou realities were closely linked to their survival rates, where fluctuating caribou survival was reflected in cyclic population trends and associated with changes in caribou behaviour and health status. TKKs described a general abundance cycle for DU caribou, where, for years, people would "never see a single live animal" (Ekaluktutiak TKK 1), and then there were so many caribou that they were "lining up outside the houses" (Kugluktuk TKK 7). More specifically, Ekaluktutiak and Kugluktuk TKKs described seeing fewer DU caribou from approximately the 1920s until the 1950s, after which both communities reported an increase in DU caribou sightings (Fig. 7). Kugluktuk TKKs described many DU caribou through 1970-80, when "there were lots of caribou right in town, migrating through" (Kugluktuk TKK 7). This trend shifted and by 2003 Kugluktuk TKKs noted that DU caribou were no longer found around the airport:
TABLE 1. Percentage of DU caribou range identified by the TKKs during the 2003 interviews mapped inside and outside the official DU caribou range used in the ECCC (2018) management plan range.

\begin{tabular}{lcc}
\hline \hline DU caribou range by TKKs & $\begin{array}{c}\text { Inside ECCC } \\
(2018) \text { range }\end{array}$ & $\begin{array}{c}\text { Outside ECCC } \\
(2018) \text { range }\end{array}$ \\
\hline Both communities & $81 \%$ & $19 \%$ \\
Ekaluktutiakmiut (total) & $96 \%$ & $4 \%$ \\
Summer & $95 \%$ & $5 \%$ \\
Winter & $100 \%$ & $0 \%$ \\
Kugluktukmiut (total) & $76 \%$ & $24 \%$ \\
Summer & $93 \%$ & $7 \%$ \\
Winter & $71 \%$ & $29 \%$ \\
\hline \hline
\end{tabular}

"the caribou used to come behind the airport, now there is hardly any caribou" (Kugluktuk TKK 14). Conversely, Ekaluktutiak TKKs said there were few caribou that were far away in the late 1960s-70s, then many DU caribou from approximately 1980 until 2003, "back to the way it used to be long ago today" (Ekaluktutiak TKK 10) and that "every year now, caribous come...right to town" (Ekaluktutiak TKK 3). In response to questions around rifle introductions, TKKs from Ekaluktutiak and Kugluktuk said that, while rifles made it easier to harvest caribou, the decline in DU caribou herd during the 1920s was not a result of rifle introduction. They said drowning rates and rain freezing the ground and blocking access to vegetation had bigger impacts on abundance during this time.

TKKs explained that variation in DU caribou behaviour was expected and related to abundance. One behaviour, DU caribou migration, only happens when there are many or enough caribou. TKKs said that when the number of caribou are too few, they do not migrate but remain on Victoria Island for the winter: "the herd never used to migrate to [the mainland] long ago but, when there were many DU caribou, the herd would migrate to the mainland for the winter. Now they migrate in the spring and fall; now it's not like long ago" (Ekaluktutiak TKK 9). They also indicated that it was normal for some DU caribou to stay on Victoria Island throughout the winter regardless of

TABLE 2. Summary of DU caribou range and harvesting range for DU caribou as mapped by the TKKs in 2003 . Values in the community overlap column consider overlapping areas.

\begin{tabular}{|c|c|c|c|c|}
\hline Range type & Total area & Ekaluktutiakmiut area & Kugluktukmiut area & Community overlap \\
\hline Total (DU caribou range \& harvesting range) & $277,100 \mathrm{~km}^{2}$ & $173,700 \mathrm{~km}^{2}$ & $193,100 \mathrm{~km} 2$ & $89,700 \mathrm{~km}^{2}$ \\
\hline $\begin{array}{l}\text { DU caribou range } \\
\text { (\% of all mapping) }\end{array}$ & $\begin{array}{c}248,200 \mathrm{~km}^{2} \\
(90 \%)\end{array}$ & $\begin{array}{c}149,100 \mathrm{~km}^{2} \\
(86 \%)\end{array}$ & $\begin{array}{c}164,200 \mathrm{~km}^{2} \\
(85 \%)\end{array}$ & $\begin{array}{c}65,000 \mathrm{~km}^{2} \\
(72 \%)\end{array}$ \\
\hline Summer & $170,800 \mathrm{~km}^{2}$ & $121,100 \mathrm{~km}^{2}$ & $78,300 \mathrm{~km}^{2}$ & $28,600 \mathrm{~km}^{2}$ \\
\hline (\% of total DU caribou range) & $(69 \%)$ & $(81 \%)$ & $(48 \%)$ & $(44 \%)$ \\
\hline Winter & $189,900 \mathrm{~km}^{2}$ & $98,600 \mathrm{~km}^{2}$ & $138,900 \mathrm{~km}^{2}$ & $47,700 \mathrm{~km}^{2}$ \\
\hline ( $\%$ of total DU caribou range) & $(76 \%)$ & $(66 \%)$ & $(85 \%)$ & $(73 \%)$ \\
\hline $\begin{array}{l}\text { Harvesting range for DU caribou } \\
\quad \text { (\% of all mapping) }\end{array}$ & $\begin{array}{l}165,300 \mathrm{~km}^{2} \\
(60 \%)\end{array}$ & $\begin{array}{l}80,200 \mathrm{~km}^{2} \\
\quad(46 \%)\end{array}$ & $\begin{array}{l}107,100 \mathrm{~km}^{2} \\
\quad(55 \%)\end{array}$ & $\begin{array}{l}22,000 \mathrm{~km}^{2} \\
\quad(25 \%)\end{array}$ \\
\hline Past (pre-2003) & $150,300 \mathrm{~km}^{2}$ & $67,200 \mathrm{~km}^{2}$ & $104,200 \mathrm{~km}^{2}$ & $21,100 \mathrm{~km}^{2}$ \\
\hline (\% of total harvesting range for DU caribou) & $(91 \%)$ & $(84 \%)$ & $(97 \%)$ & $(96 \%)$ \\
\hline “Current" (2003) & $58,100 \mathrm{~km}^{2}$ & $26,200 \mathrm{~km}^{2}$ & $32,400 \mathrm{~km}^{2}$ & $400 \mathrm{~km}^{2}$ \\
\hline (\% of total harvesting range for DU caribou) & $(35 \%)$ & $(33 \%)$ & $(30 \%)$ & $(2 \%)$ \\
\hline
\end{tabular}




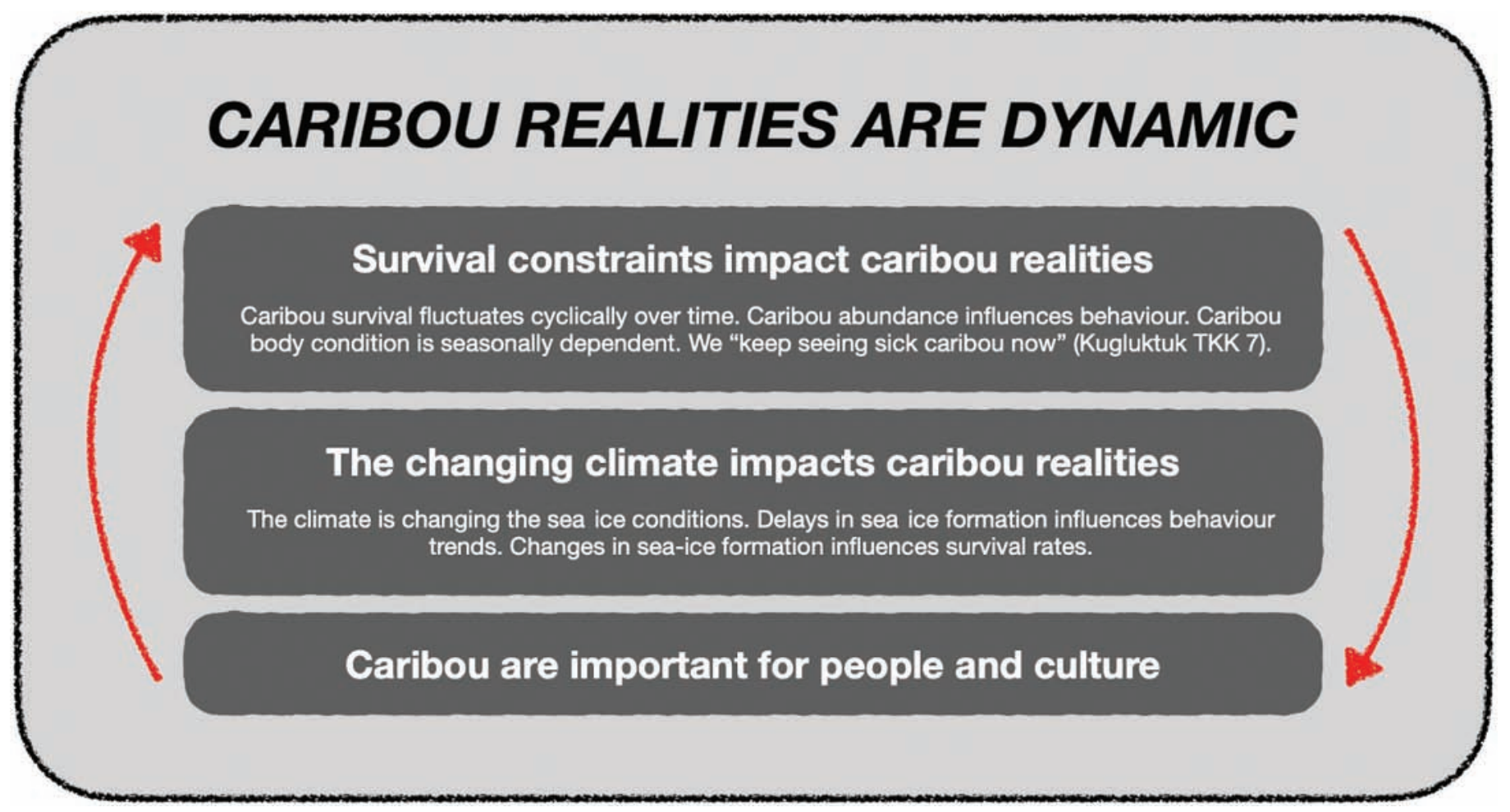

FIG. 6. Summary of the main theme that caribou realities are dynamic and the three sub-themes as defined from the interview results-survival constraints impact caribou realities, the changing climate impacts caribou realities, and caribou are important for people and culture. The sub-themes are all interconnected and influence each other to create the overarching theme.

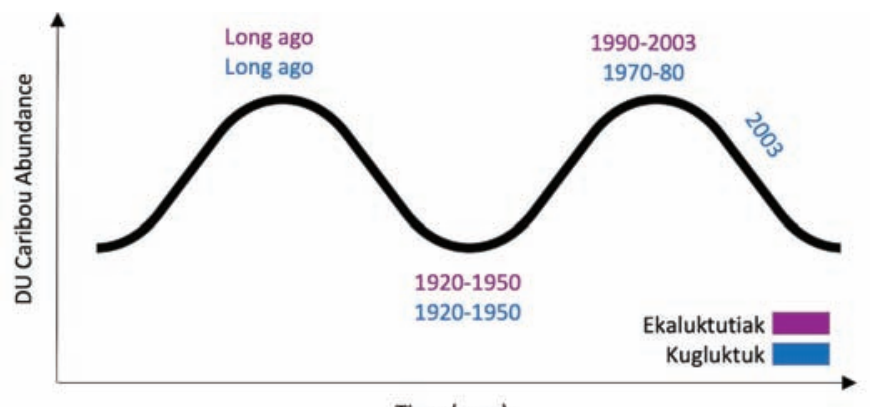

Time (year)

FIG. 7. Trends in relative abundance of DU caribou summarized from the interviews in 2003. The purple (top) time intervals represent observations from Ekaluktutiakmiut, and the blue (bottom) time intervals represent observations from Kugluktukmiut.

abundance: "now, there are caribou all year round in the winter. They are mixed with Peary caribou" (Ekaluktutiak TKK 13). TKKs explained that DU caribou abundance influences the duration of the migration: "some years when they are migrating, there are fewer caribou and they go [by] fast. And some years, there's so many caribou that they take longer to migrate through, take longer to finish migrating" (Ekaluktutiak TKK 15).

TKKs described that DU caribou body condition changed according to the seasons: DU caribou are "really fat" (Ekaluktutiak TKK 9) during the summer and fall, not bad during the winter, and skinny during the spring. Migration and rut were identified as the life stages that had the greatest influence on body condition, with Ekaluktutiakmiut primarily reporting on the influence of rut and Kugluktukmiut primarily reporting on the influence of migration. During the summer and fall, they said DU caribou had a chance to recover the accumulated nutritional debt spurred from these energetically costly life stages of the previous year.

TKKs explained that body condition could be reduced further by extreme temperatures (hot and cold), rough snow conditions, and rain during snow seasons. They said hot temperatures during the summer resulted in skinny caribou. Similarly, hard winters, which could include extreme cold, deep or hard snow, or rain that creates an ice layer on the ground surface during freezing temperatures, also resulted in skinny DU caribou. TKKs explained that, "when the snow is [very] hard" (Ekaluktutiak TKK 10), it is difficult for DU caribou to access vegetation during the winter and that "freezing rain" (Ekaluktutiak TKK 3 ), or rain that falls on snow, creates a layer of ice over the vegetation that blocks access to food and limits DU caribou nutrition. TKKs associated rain-on-snow events with massive declines in DU caribou, during which "all the caribou died off from thick rain" (Kugluktuk TKK 15) and that this had occurred in the 1920s.

Some TKKs reported observations of DU caribou with brucellosis and Taenia infections (referring to tapeworm cysts but reported by scientific name in the transcript, for example Ekaluktutiak TKK 2 in Table 3). Also, some TKKs described conditions such as "watery joints," "joints really three times the leg size," and "swollen joints," as well as tapeworm cysts in the muscle, such as "small white round cysts," "right in the meat, little cysts, look like pearls" 
TABLE 3. TKK quotes from interview transcripts that describe disease abnormalities in DU caribou.

\begin{tabular}{|c|c|}
\hline TKK & Quotes \\
\hline \multicolumn{2}{|c|}{ Ekaluktutiakmiut } \\
\hline 1 & $\begin{array}{l}\text { There's a few over the years, I've seen a bull—-the spleen was stuck to the inside and there was really green puss. It was stuck to } \\
\text { everything. It was really puffy and really pussy. Full of puss, green puss. It had crooked hooves, brucellosis. }\end{array}$ \\
\hline 2 & $\begin{array}{l}\text { Last year we got samples of caribou with brucellosis and some parasites, Taenia cysts. } \\
\text { Good, pretty healthy, couple samples with Taenia cysts. }\end{array}$ \\
\hline 3 & $\begin{array}{l}\text { Lots of caribou, some of them are full of old wounds, some of them got brucellosis, some of them have green meat, those ones I always } \\
\text { bring them back... and give them to [the Wildlife Officer], some of them have little white cysts, Taenia cysts. }\end{array}$ \\
\hline 4 & Once I seen a caribou full of white stuff, small white round cysts, in the early spring, early July. \\
\hline 7 & $\begin{array}{l}\text { Brucellosis, one time my son, he was out in the fall time, he was out and brought a nice healthy caribou, [name removed] was just } \\
\text { starting to cut the hind leg off, there was a big puss there. I brought it to Wildlife, they sent it out for testing. }\end{array}$ \\
\hline 9 & I don't really know much about the Island caribou, but I notice some of them have white cysts inside. \\
\hline 11 & Fall they are healthy, in the spring they are slimmer, some walk slow, sick, bad, green pus, brucellosis, Taenia cysts. \\
\hline \multirow[t]{2}{*}{13} & $\begin{array}{l}\text { Some of them get poor, the ones that have gone through the ice, some of them have white cysts some of them got really big, some caribou } \\
\text { get puss and really slow moving. }\end{array}$ \\
\hline & $\begin{array}{l}\text { Some are not good, when the meat turn[s] to red, they are no good, they are not to get them, not to get the meat when they turn red, they } \\
\text { have sickness and some kind of disease. }\end{array}$ \\
\hline 14 & Some caribou have big stomachs. We shoot them because they are suffering. \\
\hline \multirow[t]{2}{*}{15} & They get skinny, watery joints. One time I saw antlers stuck together. \\
\hline & Some caribou, when they are calving, they are very sick, some of them get cripple. \\
\hline \multicolumn{2}{|c|}{ Kugluktukmiut } \\
\hline 1 & I have not seen Dolphin Union caribou sick, but I have gotten reports of them though. Myself, No. \\
\hline \multirow[t]{2}{*}{3} & $\begin{array}{l}\text { Some of them they are nice, healthy alright but some of them not very good. Some of them just like they got poor legs from falling } \\
\text { through, some freeze, they get sick from saltwater too maybe some of them. Mainland caribou especially. }\end{array}$ \\
\hline & $\begin{array}{l}\text { They all mixed like poor sometimes some of them and sometimes there's, some of them are sick, some of them are fair, some of them } \\
\text { are pretty healthy, they're all not the same, mostly most of them are healthy just like. Once in a while some of them have funny bones, } \\
\text { some are no good with watery joints. }\end{array}$ \\
\hline 4 & Kind of skinny during migration, some caribou have signs of illness. \\
\hline 5 & $\begin{array}{l}\text { Some get so skinny, get funny in sickness, brucellosis. Insides are stuck to the body cavity in winter. Lungs get stuck to the body cavity, } \\
\text { ribs, and meat. Swollen joints, some hardly eat too, they get skinny. }\end{array}$ \\
\hline 6 & $\begin{array}{l}\text { Fall: nice and prime, with a lot of body fat, not very much injuries. Winter: very lean, there's some body injuries on joints }- \text { green water } \\
\text { and also right in the meat little cysts look like little pearls, a lot of them. Brucellosis, joints really three times the leg size. All full of } \\
\text { green stuff and that, a lot of water. Spring: a little bit on lean side, seem to be recovering from lack of food during the winter. They get } \\
\text { more meat on them, meatier. Bone marrow gets a lot more, better body condition, during the winter the bone marrow gets hardly any in } \\
\text { them, in the spring. Summer: occasional injuries from rocks, generally quite healthy, slim from migrating. }\end{array}$ \\
\hline 7 & $\begin{array}{l}\text { You can see some really sick. Some get enlarged hooves, enlarged joints, skinless legs, limping. Some of the caribou, sick ones are not } \\
\text { afraid, they look for food, vegetation, grazing on rock, sand. Now caribou keep being sick, keep seeing sick caribou. When we were } \\
\text { young we didn't see any sick caribou, now we see sick caribou. }\end{array}$ \\
\hline 11 & $\begin{array}{l}\text { Get skinny, meat gets swollen, when they walk too long. Kitikhyungmiuut. I don't know, but the other year there were many caribou } \\
\text { dead sitting down. In 1989, they must have starved. Bulls were dead, cows were dead. There was really skinny Dolphin Union caribou } \\
\text { around too. Curled up like sleeping, but dead. }\end{array}$ \\
\hline 12 & Perfect some of them. Sick ones, brucellosis, meat is green. Swollen. Broken jaws, crooked legs. \\
\hline 13 & $\begin{array}{l}\text { Funny feet from walking on rough areas. Yes, starting to find a few sick ones, bad meat, something wrong with the caribou, lungs, } \\
\text { Taenia cysts, lungs stuck to the chest cavity. On the feet, stuck to body, some spleen and stomach stuck together, some had big spleen, } \\
\text { enlarged spleen, stuck rumen. }\end{array}$ \\
\hline 14 & Seen a few with brucellosis, some with injuries. \\
\hline 15 & Yeah, seen few, some sick caribou with rash, funny swollen legs, pussy inside. Also see little white spots. \\
\hline
\end{tabular}

(Kugluktuk TKK 6). Kugluktukmiut described rashes and hairless legs, green meat, broken jaws, "funny bones," lungs stuck to the chest cavity, "spleen and stomach stuck together," and enlarged spleens. Ekaluktutiakmiut described "a few [sick caribou] over the years" (Ekaluktutiak TKK 1) with big stomachs, green meat or pus, irritated spleens, hoof problems, antlers stuck together, and sick caribou when calving. TKKs observed that even while some DU caribou were very healthy, sick animals were more frequently observed during the spring when DU caribou were the skinniest. Kugluktukmiut emphasized more concern about DU caribou health conditions than Ekaluktutiakmiut.

\section{Changing Climate Impacts}

TKKs described changes in climate and weather that influenced the timing of season changes and presence of wind, snow, and sea ice. They said that wind was more problematic, snow quantity was reduced, and sea ice formation was later today than in the past. Temperature and wind observations centered around sea ice formation, such that hotter and windier conditions limited sea ice formation by delaying appropriate freezing temperatures and breaking up any sea ice that formed. They reported snow-machine trails that had disappeared "in couple of days from the wind. No more ice: the ice we just traveled on is all gone and open water from the wind" (Ekaluktutiak TKK 3). Over the years, TKKs reported that community sea ice travel had been delayed from October to November and sometimes December.

TKKs said that delay in sea ice formation caused changes in DU caribou staging and migrating behaviour. They explained that when the sea ice formed later in the year, the lack of sea ice acted as a barrier to migration, which resulted in DU caribou crowding their southern Victoria Island staging area and moving farther east as they waited. 
The longer the DU caribou waited for the sea ice to form, the more "the animals seemed to get leaner" (Kugluktuk TKK 6). As the delays continued, TKKs reported some DU caribou would abandon migrating behaviour: "some of the caribou didn't migrate because they were looking for a place to cross. The ones that didn't cross they just turned around and went back inland, stayed on the island" (Ekaluktutiak TKK 2). They indicated that in 2002 the sea ice formation was very delayed and there were DU caribou near Ekaluktutiak all winter.

Changes in climate and weather with consequent delayed freeze-up of sea ice was seen to impact DU caribou safety during migration. Kugluktukmiut described massive drownings of DU caribou with "a lot of caribou drowning in the fall" and seeing "caribou being frozen in the ice" (Kugluktuk TKK 1). Some Kugluktukmiut emphasized this sentiment further, saying the 2003 DU caribou abundance was "only lower [because of] drowning" (Kugluktuk TKK 6) and they also associated the 1920 decline in part with high drowning rates. TKKs said that some DU caribou that fell through the sea ice were able to get out of the water, but it caused "a lot of the energy loss from body, [leaving] hardly any fur on them; the front legs totally no hair on them. Patches of ice on their back, all matted on backs, chunks of ice hanging. I've seen them die of hypothermia" (Kugluktuk TKK 6).

\section{Caribou are Important for People and Culture}

The inherent respect and recognition by the TKKs for DU caribou as autonomous beings were described through their narratives and the repeating of Elders' teachings. TKKs explained that, even though the land is vast, the leaders of the herd knew where and when to move. Furthermore, the Elders' teachings reflected respect for the autonomy and intelligence of DU caribou: "the old people say when you see caribou coming from inland or somewhere, you're supposed to let the leaders go by, so that they'll just keep following" (Kugluktuk TKK 1). The behaviour of DU caribou was respected through adjusted actions by people to ensure caribou would return the following years. "People need caribou" (Kugluktuk TKK 11). TKKs explained that the small number of the DU caribou from approximately 1920 to 1950 made it difficult to rely on this herd for food. TKKs relationships with the land and their ways of life adapted in response to changes in DU caribou. One Ekaluktutiak TKK describes this relationship further, sharing that their family had to move communities when there were no DU caribou in order to have more country food options. TKKs said respecting DU caribou is essential to ensuring caribou for the future.

\section{DISCUSSION}

Through analyses of archived TK interviews, we have created a valuable collective account of DU caribou based on perspectives in 2003. This account provided critical insights into DU caribou distribution, population, ecology, and disease syndromes. Kugluktukmiut observations, such as fewer animals, range contraction, and increased instances of disease, foreshadowed the declines that have resulted in the herd being reassessed as endangered today. The interviews show that these signs were not yet apparent to Ekaluktutiakmiut in 2003. The differences in accounts between communities demonstrate the cruciality of considering unique, place-based perspectives and the importance of mobilizing TK from communities and knowledge keepers throughout the caribou range for a herdlevel understanding. This understanding is particularly important for a migratory species like caribou, which has a large range and highly seasonal distribution.

\section{Historical DU Caribou Population Trends and Distribution}

The collective account described fluctuations in abundance and distribution of the DU caribou herd. The historical abundance trends reported by the two communities were similar but diverged in 1970. By 2003, Kugluktukmiut noted fewer caribou while Ekaluktutiakmiut described a peak in observed DU caribou abundance. At the same time, Kugluktukmiut observed a range contraction with the western boundary of DU caribou distribution shifting eastward and away from Kugluktuk while Ekaluktutiakmiut indicated that DU caribou were closer to their community. These changes are supported by the Northwest Territories' Species at Risk Committee (2013) report on traditional and community knowledge of DU caribou, which says that the herd's distribution trends are likely connected to abundance and migration. The divergent findings of the two communities highlight how locally observed changes in caribou abundance are reflective of geographic and seasonal experience and must be interpreted alongside observations from other communities (Ferguson et al., 1998; this study).

By combining this study with other available, documented TK, we can elucidate a detailed account of changes in DU caribou abundance and distribution over time. Kugluktukmiut said DU caribou peaked during the 1970s -80 s and were in decline in the early 2000s (Thorpe Consulting Services, 2014; this study). Umingmaktokmiut said DU caribou started to come farther south in the 1970s and mixed with mainland caribou, which suggests the southern boundary of the DU caribou distribution expanded southward to include the Umingmaktok in the 1970s (Thorpe et al., 2001; also supported by David Kaomayok in Gunn et al., 1997). Ulukhaktokmiut reported a decline in DU caribou abundance in the 1990s (Ulukhaktok TK interviews in 2011-13, as cited in ECCC, 2018). According to Ekaluktutiakmiut, DU caribou became progressively more abundant near Ekaluktutiak from the 1980s to the 2000s (Thorpe et al., 2001), regular harvesting of DU caribou was happening twice a year by 2000 (Bates, 2006), and a peak in abundance happened for DU caribou from 
the 1990s to the mid-2000s (Tomaselli et al., 2018b). These accounts suggest the herd's range was expanding towards the south and then east from the 1970s until the 1990s. Our results are consistent with the existing accounts, and timely analysis and reporting on these 2003 interviews would have indicated a change in the western boundary of DU caribou distribution and suggestions of a decline before many of these other reports were created.

The DU caribou management plan recognizes that territorial government and co-management actions should reflect where the herd is in their natural population cycle (ECCC, 2018). Described in part 2, section 6.6, this recommendation was not adopted by the competent federal Ministers because of jurisdiction restrictions (ECCC, 2018). The territorial governments detailed recommended management actions for "high," "declining," "low," and "increasing" phases of the DU caribou population cycle (ECCC, 2018). They state there is not enough information to accurately assess the herd's natural population cycle phases prior to 1997. As such, they set the peak for the high phase at the higher end of the confidence interval $(40,000)$ for the 1997 population estimate $(34,558$ animals, $95 \% \mathrm{CI}=27,757$ to 41,$359 ; \mathrm{CV}=12 \%$; Nishi and Gunn, 2004; Dumond and Lee, 2013), the declining and increasing phases between $20 \%$ and $60 \%$ of the peak, and the low phase below $20 \%$ of the peak (ECCC, 2018). According to these criteria, the survey estimates indicate that the herd was in the high phase in 1997 (86\%) and 2007 (69\%), in the declining phase in 2015 (46\%), and in the low phase in $2018(10 \%)$ and 2020 (10\%) (Nishi and Gunn, 2004; Dumond and Lee, 2013; Leclerc and Boulanger, 2018, 2020; Campbell et al., 2021). The TK accounts presented in the previous two paragraphs add nuances of abundance change, distribution change, and geographic location between 1970 and the mid-2000s to the understanding of the natural population cycle phases of DU caribou. Drawing from community-based understandings across the DU caribou herd range could help determine population cycle phases apart from survey estimates.

The analysis of the participatory maps showed that Ekaluktutiakmiut and Kugluktukmiut synergistically mapped more of the DU caribou range together than they do alone. This finding reinforces how the two communities' accounts are more comprehensive when considered together. Ekaluktutiakmiut and Kugluktukmiut individually covered approximately the same the percentage of the official DU caribou range (ECCC, 2018). Yet, the Kugluktukmiut DU caribou ranges covered more land outside of the official range than Ekaluktutiakmiut did ( $24 \%$ compared to $4 \%$ of the total ranges), particularly for the winter range $(29 \%$ of the Kugluktukmiut winter range). This discrepancy draws attention to a potential knowledge gap in the official DU caribou winter range, located in the southwest part of the herd's distribution. This southwestern portion is often attributed to barren-ground caribou (COSEWIC, 2016), as is caribou distribution on the mainland during the summer, but other TK, collar data, and survey data show these areas are also used by DU caribou
(Dumond, 2007; Campbell et al., 2021; A. Hanke, unpubl. data). It is important to manage land use across the entire range because caribou herds that persist with constricted distributions have been linked to higher cortisol levels (Ewacha et al., 2017), restricted genetic flow (Thompson et al., 2019), reduced resilience to predation (Lesmerises et al., 2019), higher susceptibility to rain-on-snow events (Macias-Fauria and Post, 2018), and a higher conservation risk (Lucas et al., 2019). The participatory mapping highlights the potential advantages and limitations of TK in conservation settings and reinforces the importance of ensuring multi-community representation to obtain a comprehensive understanding of a migratory species with a large range.

\section{Historical DU Caribou Ecology}

This study and others have detailed the distribution of DU caribou and its dependence on seasonality, population trends, weather, and climate (see Poole et al., 2010; Dumond and Lee, 2013; ECCC, 2018; Leclerc and Boulanger, 2018). These 2003 TK accounts have provided important additional information on how DU caribou use their range. TKKs mapped DU caribou year-round on both Victoria Island and the mainland, which is consistent with the results of Thorpe Consulting Services (2014). Variably, the management plan reports that DU caribou are on Victoria Island in the winter and summer only during periods of population lows (ECCC, 2018). TKKs also explained that the southern extent of the DU caribou distribution expands as the DU caribou population increases, eventually allowing for migration across the sea ice to winter on the mainland during recovery periods. These findings are perhaps consistent with density-dependent distribution based on land-carrying capacity (Bergerud et al., 2008; Le Corre et al., 2019) and the study by Ferguson et al. (1998), which showed a connection between distribution and abundance changes in South Baffin caribou. Altogether, understanding interannual change in distribution of DU caribou within their range will help predict how this herd will be impacted by habitat changes and will make various types of conservation assessments more accurate, including population surveys (Boakes et al., 2018; Lucas et al., 2019; Campbell et al., 2021).

TKKs described how delays in sea ice formation delay migration and, when the delays in sea ice formation were severe, how some DU caribou abandoned migration and stayed on Victoria Island for the winter. There are no instances of collared DU caribou remaining on Victoria Island for the winter past 1989 (Poole et al., 2010; Leclerc et al., 2018), but Poole et al. (2010) did report increased staging time and directional movement along the coast during years of late sea-ice formation. TKKs said that the 1920s DU caribou decline was caused by a rain-on-snow events that blocked caribou access to vegetation. This claim contrasts with the COSEWIC $(2004,2017 b)$ reports that attribute this decline, at least partially, to the introduction of firearms. 
Rain-on-snow events are recognized as a concern for DU caribou (Gunn and Fournier, 2000; COSEWIC, 2017b), and heavy pack snow is documented to cause caribou dieoffs (Dolant et al., 2018). Forbes et al. (2016) connected increased sea ice loss with more frequent and intense rainon-snow events in West Siberia. The future impact and interactions amongst climate changes, sea ice changes, and rain-on-snow events are uncertain and should remain a concern for DU caribou (COSEWIC, 2017b; ECCC, 2018).

\section{Historical DU Caribou Disease Syndromes}

TKKs described the presence of various DU caribou disease syndromes. The most common included swollen or watery leg joints and limping caribou, consistent with and referred to by some TKKs as brucellosis, and little, white cysts in the meat, which are consistent with and referred to by some as Taenia cysts. Also, TKKs described rashes or hairlessness on legs, symptoms often associated with Besnoitia tarandus infection (Tryland and Kutz, 2019), lungs stuck to the chest cavity, spleen stuck to rumen, abnormal or enlarged spleens, and green pus or meat, consistent with a variety of infectious disease processes.

Rangiferine brucellosis, caused by Brucella suis biovar 4, is a zoonotic (transmissible to people from animals) bacterium that negatively affects reproduction and productivity in caribou (Forbes, 1991; Tryland and Kutz, 2019). While TKKs reported several observations of brucellosis-like symptoms (swollen or watery leg joints and limping caribou), we could not determine from the transcripts if this was a new and emerging syndrome in 2003 or just normal. Other reports do, however, support an emergence of this pathogen in DU caribou in the 1990s. Brucellosis was apparently rare or absent on Victoria Island historically, with zero of 62 caribou collected in April 1987-90 from southeastern Victoria Island (probably DU caribou) testing positive by serology (Gunn et al., 1991). Ekaluktutiakmiut and local knowledge keepers started to observe DU caribou with swollen joints and limping in the 1980s, with increasing frequency in 1990s (Tomaselli et al., 2018b). In 2015-16, seroprevalence was $15 \%(\mathrm{CI}: 6-29, \mathrm{n}=41)$ in female DU caribou, which was higher than that reported in most barrenground caribou herds (Carlsson et al., 2019).

Descriptions of white cysts in meat are consistent with Taenia spp., and Taenia krabbei is a common cestode found in the musculature of caribou. At high infection intensity, harvesters have reported impacts on body condition; however, infection intensity is often low and clinical signs are rare (Tryland and Kutz, 2019). Ekaluktutiakmiut and local knowledge keepers reported the presence of white muscle cysts in DU caribou since the 1980s and 1990s (Tomaselli et al., 2018b). However, Gunn et al (1991) reported fewer complaints about T. krabbei in caribou from southern Victoria Island (probably DU caribou) than from the mainland (probably barren-ground caribou).

Kugluktukmiut descriptions in the 2003 interviews of rashes and hairlessness on legs are consistent with infection of Besnoitia tarandi. This protozoan is commonly seen in barren-ground caribou throughout North America as tissue cysts in the skin, subcutaneous tissues, and periosteum of the lower legs, and it causes skin thickening and hair loss (Ducrocq et al., 2012). In 2014, Ekaluktutiakmiut and local knowledge keepers reported a sandpaper-like feeling in DU caribou since the 1980s, which was stable or increasing between 1990 and 2000 (Tomaselli et al., 2018b). Gunn et al. (1991) reported Besnoitia in 6 of 82 caribou cows sampled from southeastern Victoria Island in April 1987-90. The Ekaluktutiakmiut accounts from our study, however, do not indicate the presence of besnoitiosislike syndromes. Possible reasons for differences between the 2003 interviews and the studies mentioned here may include the study objectives (ecology versus health) or that the symptoms had just been normalized and not considered an abnormal finding (see Armitage and Kilburn, 2015; Tilley, 2016; Tomaselli et al., 2018b).

The remainder of the syndromes reported by the TKKs are non-specific descriptions. Pleuritis and peritonitis could both result in fibrin deposition, as described with the lungs stuck to the chest cavity and the spleen stuck to the rumen; these could be symptoms associated with various infectious causes (Tryland and Kutz, 2019). A systemic infection, acute stress (e.g., chase from the hunt), or as a haemorrhagic syndrome are some possible explanations for abnormal or enlarged spleens (Josefsen et al., 2018; Lian et al., 2018). Nutritional deficiencies, resolution of hematoma, or a bacterial or parasitic infection could be associated with green pus or meat (Tryland and Kutz, 2019). Previous literature reported a discoloured lung that was stuck to the rib cage and observations of yellow subcutaneous tissue (Tomaselli et al., 2018b) and, of 62 necropsies, one cow with a recently fractured rib, pneumonic patches, and extreme emaciation and another with a polycystic kidney (Gunn et al., 1991).

\section{Unique Community-based Perspectives}

Our results showed that TK insights depend on the context of the setting in which they are developed. That is, differing accounts from Ekaluktutiak and Kugluktuk, describing the same herd at the same time reflected the different spatial and temporal relationships of the two communities with DU caribou. In Ekaluktutiak, the accounts described a stable DU caribou abundance with healthy animals that were close to the community in 2003; in contrast, Kugluktuk accounts described a declining DU caribou abundance with animals that were sick and far from the community in 2003. When discussing body condition, Ekaluktutiakmiut emphasized the rut whereas Kugluktukmiut emphasized migration. These observations spatially align with the community closer to where these behaviours take place.

In the context of northern wildlife management, the integral nature of space is addressed in the Wildlife Management Advisory Council's (North Slope) reference 
guide for TK research, which states that the spatial component of TK is part of the social-ecological nature of the knowledge (Armitage and Kilburn, 2015). Our results support that wildlife management should emphasize relational, localized knowledge for environmental protection and, as a result, minimize the risk of erroneously abstracting place-specific TK to system-level understandings (e.g., Bhattacharyya and Slocombe, 2017). Specifically, TKKs interact with DU caribou, a migratory, large-range species, during different life stages depending on the seasons and locations they hunt and travel in. These interactions are reflected in the TKKs' unique insights into specific parts of the DU caribou life and ecosystem. These findings highlight the importance of taking into account TK from multiple TKKs throughout the range to develop a herd-level understanding of DU caribou.

\section{Data Considerations and Using TK in Wildlife Management}

Returning to archived TK after nearly 20 years came with unique obligations and considerations. First, we had a responsibility to complete the 2003 study and be responsive to the original ethical commitment to the research before doing new work on the topic (McGrath, 2019). The TK was documented through audio-recorded and transcribed interviews. As such, we were required to adhere to qualitative fields of inquiry, which means we needed to engage in reflective practices that queried our assumptions in reality and truth in order to account for these assumptions in our data interpretation and results (Mauthner and Parry 2009). Returning to this TK with community engagement and a detailed methodology section has allowed us to maintain relational accountability with the communities (McGrath, 2019) and fulfill standards in qualitative research (Mauthner and Parry, 2009).

The question remains whether this information, with early signals of a declining population and the emphasis on the importance of multi-community insights, would have changed the course of management or research had it been available to decision makers 18 years ago. Several reports (Golder Associates, 2003; COSEWIC, 2004, 2017b; SARC, 2013; Thorpe Consulting Services, 2014; ECCC, 2018), a few peer-reviewed published articles (Bates, 2007; Tomaselli et al., 2018a, b), a book (Thorpe et al., 2001), and a thesis (Bates, 2006) have documented or compiled TK on DU caribou. All but two of these documents have been produced since 2003; only Tomaselli et al. (2018b) clearly articulated multiple health indicators consistent with a decline, and none of them explicitly consolidate and connect community observed abundance and distribution changes across the TK accounts. Further, the COSEWIC (2004) assessment did not draw on Thorpe et al. (2001), which includes information on DU caribou distribution changes. The Species at Risk Committee (2013) included a comprehensive TK report on DU caribou, and the COSEWIC (2017b) reassessment and ECCC (2018) management plan followed suit and drew from more accessible TK sources, yet some key information on abundance and distribution remains missing (e.g., Bates, 2006; Thorpe Consulting Services, 2014). We have seen, over time, an increase in the amount of documented TK and the uptake of it in assessments and management plans. There is a need for increased coordination between those creating documented TK accounts and those writing the reports to ensure the widest pool of available evidence is accessed to inform conservation.

The Species at Risk Committee (2013) report, COSEWIC (2017b) reassessment, and ECCC (2018) management plan included additional TK from consultation meetings. However, the unpublished records of these meetings are often inaccessible, reducing transparency of the process (Hill et al., 2019), and are facilitated at different scopes (the achievable breadth and depth of understanding) than research studies (Tilley, 2016). By publishing the results of these 2003 TK interviews, we aim to make this knowledge accessible in the peer-reviewed literature (Tomasini, 2018), and to build availability and credibility for its use in conservation (e.g., COSEWIC, 2015b). We also aim to connect this TK to other documented TK on DU caribou, with the end goal of deepening understanding and furthering conversations around DU caribou. Perhaps the most important lesson, though, is the critical need to ensure timely documentation, critical analyses (including community input and peer review), and mobilization of TK, making it both reliable and readily accessible to inform management decisions and support land claim agreements.

Throughout the 2003 interviews and in the 2019 community meetings, harvesters emphasized that caribou were important for their people and a part of their culture. In the interviews, people talked about caribou being their own creatures, in control of the way they behaved and deserving of respect and care. This is not a novel finding for Ekaluktutiakmiut and Kugluktukmiut (e.g., Thorpe et al., 2001; Bates, 2006; Dumond, 2007; Thorpe Consulting Services, 2014; Tomaselli et al., 2018a), nor for other Indigenous peoples (e.g., Kendrick et al., 2005; Wray and Parlee, 2013). Further, these merits are reflected in the Nunavut Land Claims Agreement (INAC, 1993), the Nunavut Wildlife Act (Government of Canada, 1993), and elsewhere in organizations for the Nunavut Land Claims Agreement and departments of the Government of Nunavut (Lévesque, 2014). For instance, the Wildlife Act legislated 13 guiding principles and concepts of Inuit Qaujimajatuqangit, including Ikpigusuttiarniq Nirjutilimaanik/Pitiaklugit nekyutit, which means that all wildlife should be treated respectfully.

We have seen transformations of past Canadian governance structures and legislation to reflect Inuit values within organizations for the Nunavut Land Claims Agreement and departments of the Government of Nunavut (Lévesque, 2014). However, tensions remain between the Government of Nunavut and the communities regarding the appropriate use of TK in co-management, even with the increased use of this knowledge in DU caribou management 
(Government of Nunavut, 2020; Roberto-Charron, 2020; A. Hanke, unpubl. data). Some scholars argue that the philosophical mismatch between Western management and Indigenous worldviews results in the devaluing and sometimes misuse of Indigenous knowledge because of a need to adhere to Canadian governance structures within Nunavut and at the federal level (White, 2006; Bates, 2007; Ljubicic et al., 2018). For DU caribou, we see the retention of Western values in fundamental conservation tools. Reports are often written in English (with Inuinnaqtun summaries) and follow standard layouts that include distinct sections for population, distribution, and threats. Indeed, this paper reflects Western values too, as it was written in English, underwent scientific peer review, and was published as a journal article (Loseto et al., 2020).

Joe Copper Jack, a Yukon First Nation Elder and Dan Ke knowledge holder, developed a Land and Peoples Relationship Model (2020) to guide collaborative knowledge-building processes. The model relies on Yukon First Nation laws of respect, care, and share and incorporates a "no voice perspective." This perspective means that those with "no voice," like caribou, symbolically sit at the decision-making table while those literally present contribute what they think represents the "no voice's" reaction to the discussion. These reactions are then used during the decision-making process. The serious consideration of those with "no voice" in environmental decision-making is an example that challenges Western society's tendency to view the natural world as a commodity (Wilson, 2019; McGregor et al., 2020). These calls and others to decolonize and diversify academic research (Pedersen et al., 2020; Wong et al., 2020) and environmental decision-making (Tomasini, 2018; Salomon et al., 2019; Wheeler et al., 2020) have increased over the past few years, suggesting that they are the next steps needed for timely, effective, and equitable environmental governance. It will be exciting to see how wildlife conservation within Nunavut and regarding species significant to Nunavummuit continues to transform and become more inclusive of TK and effective at protecting species for the future.

\section{CONCLUSION}

This historical TK both foreshadowed a decline of the DU caribou herd and provided important insights on the ecology, health, and variability over space and time that are still relevant today. Further, our results suggest that careful philosophical deliberation, like discussions and decisions around study methodology, methods, and analytical frameworks, and diverse partner involvement are crucial in this type of research because of the intimate role DU caribou and other animals play in the lives of Ekaluktutiakmiut and Kugluktukmiut. While co-management has improved the quantity of TK that is used in decision making for DU caribou (COSEWIC, 2004, 2017b; ECCC, 2018), there remains a need for better trans-systemic interpretation of the TK (Government of Nunavut, 2020), including wider decolonialization and diversification of management and research (Pedersen et al., 2020; Wheeler et al., 2020). Moving forward in DU caribou conservation, this study provides valuable insights on the connections between community-based accounts of DU caribou abundance, distribution, and behaviour and how they can be better used to inform herd-level management actions.

\section{ACKNOWLEDGEMENTS}

We thank Ida Kapakatoak for translating and transcribing the interviews in 2003, the knowledge keepers who took part in the interviews in 2003, and Ashley Newman for her role in digitizing the participatory maps. We would also like to recognize the support this work received from the Ekaluktutiak Hunters and Trappers Organization, Kugluktuk Angoniatit Association, and the Government of Nunavut.

A. Hanke was funded by the Natural Sciences and Engineering Research Council of Canada (NSERC) Graduate Scholarship - Master's, Mitacs Accelerate IT14527 internship with Thorpe Consulting Services, the Gunther Abrahamson Management Award sponsored by Beverly and Qamanirjuaq Management Board and coordinated by the Association of Canadian Universities for Northern Studies. This work was supported by Polar Knowledge Canada Grant NST-1718-0015, NSERC Discovery Grant RGPIN/04171-2014, NSERC Northern Supplement RGPNS/316244-2014, Environment and Climate Change Canada Project GCXE20C347, Canada North Outfitting, the Northern Scientific Training Program, and Irving Maritime Shipbuilding.

\section{REFERENCES}

Armitage, P., and Kilburn, S. 2015. Conduct of traditional knowledge research-A reference guide. Whitehorse, Yukon: Wildlife Management Advisory Council North Slope.

https://wmacns.ca/resources/conduct-traditional-knowledgeresearch-reference-guide/

Bartlett, C., Marshall, M., and Marshall, A. 2012. Two-eyed seeing and other lessons learned within a co-learning journey of bringing together Indigenous and mainstream knowledges and ways of knowing. Journal of Environmental Studies and Sciences 2(4):331-340. https://doi.org/10.1007/s13412-012-0086-8

Bates, P. 2006. Knowing caribou: Inuit, ecological science and traditional ecological knowledge in the Canadian North. PhD thesis, University of Aberdeen, Aberdeen, Scotland.

- 2007. Inuit and scientific philosophies about planning, prediction, and uncertainty. Arctic Anthropology 44(2):87- 100 .

https://doi.org/10.1353/arc.2011.0065

Bergerud, A.T., Luttich, S.N., and Camps, L. 2008. The return of caribou to Ungava. Montreal: McGill-Queen's University Press. 
Bernes, C., Bråthen, K.A., Forbes, B.C., Speed, J.D.M., and Moen, J. 2015. What are the impacts of reindeer/caribou (Rangifer tarandus L.) on Arctic and alpine vegetation? A systematic review. Environmental Evidence 4: 4.

https://doi.org/10.1186/s13750-014-0030-3

Bhattacharyya, J., and Slocombe, S. 2017. Animal agency: Wildlife management from a kincentric perspective. Ecosphere 8(10): e01978.

https://doi.org/10.1002/ecs2.1978

Boakes, E.H., Isaac, N.J.B., Fuller, R.A., Mace, G.M., and McGowan, P.J.K. 2018. Examining the relationship between local extinction risk and position in range. Conservation Biology 32(1):229-239.

https://doi.org/10.1111/cobi.12979

Braun, V., and Clarke, V. 2006. Using thematic analysis in psychology. Qualitative Research in Psychology 3(2):77-101. https://doi.org/10.1191/1478088706qp063oa

- 2013. Successful qualitative research: A practical guide for beginners. Thousand Oaks, California: SAGE Publications.

- 2021. Can I use TA? Should I use TA? Should I not use TA? Comparing reflexive thematic analysis and other patternbased qualitative analytic approaches. Counselling and Psychotherapy Research 21(1):37-47.

https://doi.org/10.1002/capr.12360

Campbell, M., Ringrose, J., Boulanger, J., Roberto-Charron, A., Methuen, K., Mutch, C., Davidson, T., and Wray, C. 2021. An aerial abundance estimate of the Dolphin and Union caribou (Rangifer tarandus groenlandicus ' pearyi) herd, Kitikmeot Region, Nunavut - Fall 2020. GN Technical Report Series No. 01-2021. Iqaluit: Government of Nunavut, Department of Environment.

https:/gov.nu.ca/sites/default/files/wildlife___20210301_du_ fall_2020_caribou_survey_file_report_feb_1_2021_final.pdf

Canadian Coast Guard. 2020. Notices to Mariners 1 to 46: Annual edition 2020. Ottawa: Fisheries and Oceans Canada, Government of Canada.

Carlsson, A.M., Curry, P., Elkin, B., Russell, D., Veitch, A., Branigan, M., Campbell, M., et al. 2019. Multi-pathogen serological survey of migratory caribou herds: A snapshot in time. PLoS ONE 14(7): e0219838.

https://doi.org/10.1371/journal.pone.0219838

Chiu, A., Goddard, E., and Parlee, B. 2016. Caribou consumption in northern Canadian communities. Journal of Toxicology and Environmental Health 79(16-17):762-797. https://doi.org/10.1080/15287394.2016.1174011

COSEWIC (Committee on the Status of Endangered Wildlife in Canada). 2004. COSEWIC assessment and update status report on the Peary caribou Rangifer tarandus pearyi and barrenground caribou Rangifer tarandus groenlandicus Dolphin and Union population in Canada. Ottawa: COSEWIC.

2011. Designatable units for caribou (Rangifer tarandus) in Canada. Ottawa: COSEWIC.

2014a. COSEWIC assessment and status report on the caribou Rangifer tarandus, Newfoundland population, Atlantic-Gaspésie population, Boreal population, in Canada. Ottawa: COSEWIC. 2014b. COSEWIC assessment and status report on the caribou Rangifer tarandus, Northern Mountain population, Central Mountain population, Southern Mountain population in Canada. Ottawa: COSEWIC.

- 2015a. COSEWIC assessment and status report on the Peary caribou Rangifer tarandus pearyi in Canada. Ottawa: COSEWIC.

- 2015b. Instructions for the preparation of COSEWIC status reports. Ottawa: COSEWIC.

- 2016. COSEWIC assessment and status report on the caribou Rangifer tarandus barren-ground population in Canada. Ottawa: COSEWIC.

2017a. COSEWIC assessment and status report on the caribou, Rangifer tarandus, Eastern Migratory population and Torngat Mountains population, in Canada. Ottawa: COSEWIC.

- 2017b. COSEWIC assessment and status report on the caribou, Dolphin and Union population, Rangifer tarandus, in Canada. Ottawa: COSEWIC.

Dolant, C., Montpetit, B., Langlois, A., Brucker, L., Zolina, O., Johnson, C.A., Royer, A., and Smith, P. 2018. Assessment of the barren-ground caribou die-off during winter 2015-2016 using passive microwave observations. Geophysical Research Letters 45(10):4908-4916.

https://doi.org/10.1029/2017GL076752

Ducrocq, J., Beauchamp, G., Kutz, S., Simard, M., Elkin, B., Croft, B., Taillon, J., et al. 2012. Comparison of gross visual and microscopic assessment of four anatomic sites to monitor Besnoitia tarandi in barren-ground caribou (Rangifer tarandus). Journal of Wildlife Diseases 48(3):732-738, https://doi.org/10.7589/0090-3558-48.3.732

Dumond, M. 2007. Western Kitikmeot Caribou Workshop. Final Wildlife Report No. 19. Iqaluit: Department of Environment, Government of Nunavut.

https://www.gov.nu.ca/sites/default/files/western $\% 20$ kitikmeot $\% 20$ caribou $\% 20$ workshop $\% 20-\% 20$ final $\% 20$ wildlife\%2019.pdf

Dumond, M., and Lee, D.S. 2013. Dolphin and Union caribou herd status and trend. Arctic 66(3):329-337.

https://doi.org/10.14430/arctic4311

ECCC (Environment and Climate Change Canada). 2018. Management plan for the barren-ground caribou (Rangifer tarandus groenlandicus), Dolphin and Union population, in Canada: Adoption of the management plan for the Dolphin and Union Caribou (Rangifer tarandus groenlandicus ' pearyi) in the Northwest Territories and Nunavut. Ottawa: ECCC. https://publications.gc.ca/collections/collection_2018/eccc/ En3-5-95-2018-eng.pdf

Ewacha, M.V.A., Roth, J.D., Anderson, W.G., Brannen, D.C., and Dupont, D.L.J. 2017. Disturbance and chronic levels of cortisol in boreal woodland caribou. The Journal of Wildlife Management 81(7):1266-1275.

https://doi.org/10.1002/jwmg.21288

Ferguson, M.A.D., Williamson, R.G., and Messier, F. 1998. Inuit knowledge of long-term changes in a population of Arctic tundra caribou. Arctic 51(3):201-219.

https://doi.org/10.14430/arctic1062 
Forbes, B.C., Kumpula, T., Meschtyb, N., Laptander, R., MaciasFauria, M., Zetterberg, P., Verdonen, M., et al. 2016. Sea ice, rain-on-snow and tundra reindeer nomadism in Arctic Russia. Biology Letters 12(11): 20160466. https://doi.org/10.1098/rsbl.2016.0466

Forbes, L.B. 1991. Isolates of Brucella suis biovar 4 from animals and humans in Canada 1982-1990. Canadian Veterinary Journal 32(11):686-688.

Golder Associates. 2003. Inuit Qaujimajatuqangit literature review, gap analysis and workshop results related to the Doris North Project: North Bay Belt, Nunavut. 20 Queen Street West, Suite 2300, Toronto, Ontario M5H 3R3, Canada.

Government of Canada. 1993. Consolidation Nunavut Act S.C. 1993, c. 28. Ottawa: Minister of Justice. https://laws-lois.justice.gc.ca/PDF/N-28.6.pdf

___ 2011. Canada Gazette Part II: Statutory instruments 2011 SOR/2011-5 to 30 and SI/2011-9 to 14. Ottawa: Queen's Printer for Canada.

https://wildlife-species.canada.ca/species-risk-registry/ virtual_sara/files/orders/g2-14504ii_e.pdf

Government of Nunavut. 2020. Dolphin and Union caribou: Teleconference with hunters and trappers organizations and co-management partners: Meeting minutes and speaking points. June 18, 2020. Iqaluit: Department of Environment.

Gunn, A., and Fournier, B. 2000. Caribou herd delimitation and seasonal movements based on satellite telemetry on Victoria Island, 1987-89. File Report No. 125. Yellowknife: Government of Northwest Territories, Department of Resources, Wildlife and Economic Development.

https://www.enr.gov.nt.ca/sites/enr/files/file_reports/caribou_ herd_delimitation.pdf

Gunn, A., Leighton, T., and Wobeser, G. 1991. Wildlife disease and parasites in the Kitikmeot region, 1984-90. Kugluktuk: Government of Northwest Territories, Department of Renewable Resources.

Gunn, A., Buchan, A., Fournier, B., and Nishi, J. 1997. Victoria Island caribou migrations across the Dolphin and Union Strait and Coronation Gulf from the mainland coast, 1976-94. Manuscript Report No. 94. Yellowknife: Government of Northwest Territories, Department of Resources, Wildlife and Economic Development. https://www.enr.gov.nt.ca/sites/enr/files/94.pdf

Hanke, A., and Kutz, S. 2020. Kitikmeot traditional knowledge studies on Dolphin and Union caribou, 2003 and 2018-2020 (Rangifer tarandus groenlandicus $\mathrm{x}$ pearyi, island tuktu). Research update. Calgary, Alberta: University of Calgary. https://people.ucalgary.ca/ kutzrg/DU_TK_Report_final_ IQ.pdf

Hill, C.J., Schuster, R., and Bennett, J.R. 2019. Indigenous involvement in the Canadian species at risk recovery process. Environmental Science \& Policy 94:220-226. https://oi.org/10.1016/j.envsci.2019.01.017

Honeycutt, D. 2012. More adventures in overlay: Counting overlapping polygons with spaghetti and meatballs. ArcGIS Blog.

https://www.esri.com/arcgis-blog/products/arcgis-desktop/ analytics/more-adventures-in-overlay-counting-overlappingpolygons-with-spaghetti-and-meatballs/
INAC (Indian and Northern Affairs Canada). 1984. The Western Arctic claim: The Inuvialuit Final Agreement. Bill C-49. Ottawa: INAC.

https://www.eia.gov.nt.ca/sites/eia/files/inuvialuit_final_ agreement_0.pdf

-1993. Agreement between the Inuit of the Nunavut Settlement Area and Her Majesty the Queen in right of Canada. Ottawa: INAC.

https://www.tunngavik.com/documents/publications/LAND_ CLAIMS_AGREEMENT_NUNAVUT.pdf

Jack, J.C. 2020. Land and peoples relationship model. Powerpoint presentation. Guelph, Ontario: Conservation through Reconciliation Partnership.

https://conservation-reconciliation.ca/virtual-campfire-seriesrecordings/land-relations-planning-and-indigenous-protectedand-conserved-areas

Josefsen, T.D., Mørk, T., and Nymo, I.H. 2018. Bacterial infections and diseases. In: Tryland, M., and Kutz, S.J., eds. Reindeer and caribou: Health and disease. Boca Raton, Florida: CRC Press, Taylor \& Francis Group. 237-272. https://doi.org/10.1201/9780429489617-7

Katz, S. 2010. Traditional knowledge in caribou ecology: Vegetation à caribou à wolf food chain. Inuvik: Aurora Research Institute.

https://www.gwichin.ca/publications/traditional-knowledgecaribou-ecology-vegetation-caribou-wolf-food-chain

Kendrick, A., Lyver, P.O.'B., and Łutsël K’é Dene First Nation. 2005. Denésọliné (Chipewyan) knowledge of barren-ground caribou (Rangifer tarandus groenlandicus) movements. Arctic 58(2):175-191.

https://doi.org/10.14430/arctic409

Kourantidou, M., Hoover, C. and Bailey, M. 2020. Conceptualizing indicators as boundary objects in integrating Inuit knowledge and Western science for marine resource management. Arctic Science 6(3):279-306.

https://doi.org/10.1139/as-2019-0013

Leclerc, L.-M., and Boulanger, J. 2018. Fall population estimate of the Dolphin and Union caribou herd (Rangifer tarandus groenlandicus $x$ pearyi) Victoria Island, October 2015 and demographic population indicators 2015-2017. Status Report 2018-10. Kugluktuk: Government of Nunavut, Department of Environment.

https://www.nwmb.com/iku/2013-11-09-01-41-51/2013-1109-01-47-14/regular-meetings/2018-1/rm-004-2018/inuktitut7/7310-tab-2c-gn-doe-science-report-dolphin-and-unioncaribou-research-results-eng-1/file

- 2020. Population estimate of the Dolphin and Union caribou herd (Rangifer tarandus groenlandicus x pearyi) coastal survey, October 2018 and demographic indicators. Kugluktuk: Government of Nunavut, Department of Environment.

https:/www.gov.nu.ca/sites/default/files/final_report_2018 dolphin_and_union_caribou_abundance_survey.pdf

Le Corre, M., Dussault, C., and Côté, S.D. 2019. Where to spend the winter? The role of intraspecific competition and climate in determining the selection of wintering areas by migratory caribou. Oikos 129(4):512-525.

https://doi.org/10.1111/oik.06668 
Lesmerises, F., Johnson, C.J., and St-Laurent, M.-H. 2019. Effect of behavioral marginality on survival of an alpine ungulate. Ecosphere 10(7): e02806.

https://doi.org/10.1002/ecs2.2806

Lévesque, F. 2014. Revisiting Inuit Qaujimajatuqangit: Inuit knowledge, culture, language, and values in Nunavut institutions since 1999. Éudes Inuit Studies 38(1/2):115-136. https://doi.org/10.7202/1028856ar

Lian, M., Evans, A.L., Beckmen, K.B., Caulkett, N.A., and Arnemo, J.M. 2018. Restraint and immobilization. In: Tryland, M., and Kutz, S.J., eds. Reindeer and caribou: Health and disease. Boca Raton, Florida: CRC Press, Taylor \& Francis Group. 465-492. https://doi.org/10.1201/9780429489617-15

Ljubicic, G., Okpakok, S., Robertson, S., and Mearns, R. 2018. Uqsuqtuurmiut inuita tuktumi qaujimaningit (Inuit knowledge of caribou from Gjoa Haven, Nunavut): Collaborative research contributions to co-management efforts. Polar Record 54(3):213-233. https://doi.org/10.1017/S0032247418000372

Loseto, L.L., Breton-Honeyman, K., Etiendem, D.N., Johnson, N., Pearce, T., Allen, J., Amos, A., et al. 2020. Indigenous participation in peer review publications and the editorial process: Reflections from a workshop. Arctic Science 6(3):352-360. https://doi.org/10.1139/AS-2020-0023

Lucas, P.M., González-Suárez, M., and Revilla, E. 2019. Range area matters, and so does spatial configuration: Predicting conservation status in vertebrates. Ecography 42(6):1103 - 1114. https://doi.org/10.1111/ecog.03865

Macias-Fauria, M., and Post, E. 2018. Effects of sea ice on Arctic biota: An emerging crisis discipline. Biology Letters 14(3): 20170702. https://doi.org/10.1098/rsbl.2017.0702

Mantyka-Pringle, C.S., Jardine, T.D., Bradford, L., Bharadwaj, L., Kythreotis, A.P., Fresque-Baxter, J., Kelly, E., et al. 2017. Bridging science and traditional knowledge to assess cumulative impacts of stressors on ecosystem health. Environment International 102:125-137.

https://doi.org/10.1016/j.envint.2017.02.008

Mauthner, N.S., and Parry, O. 2009. Qualitative data preservation and sharing in the social sciences: On whose philosophical terms? Australian Journal of Social Issues 44(3):291 - 307. https://doi.org/10.1002/j.1839-4655.2009.tb00147.x

Maxwell, J.A., and Mittapalli, K. 2010. Realism as a stance for mixed methods research. In: Tashakkori, A., and Teddlie, C., eds. SAGE handbook of mixed methods in social \& behavioral research, $2^{\text {nd }}$ ed. Thousand Oaks, California: SAGE Publications. $145-168$. https://doi.org/10.4135/9781506335193.n6

McGrath, J.T. 2019. The qaggiq model: Towards a theory of Inuktut knowledge renewal. Iqaluit: Nunavut Arctic College Media.

McGregor, D., Whitaker, S., and Sritharan, M. 2020. Indigenous environmental justice and sustainability. Current Opinion in Environmental Sustainability 43:35-40.

https://doi.org/10.1016/j.cosust.2020.01.007
Nishi, J.S., and Buckland, L. 2000. An aerial survey of caribou on western Victoria Island (5-17 June 1994). File Report No. 128. Yellowknife: Government of Northwest Territories, Department of Resources, Wildlife and Economic Development.

https://www.enr.gov.nt.ca/sites/enr/files/file_reports/aerial_ survey_of_caribou.pdf

Nishi, J.S., and Gunn, A. 2004. An estimate of herd size for the migratory Dolphin and Union caribou herd during the rut (17-22 October 1997). File Report No. 131. Yellowknife: Government of Northwest Territories, Department of Resources, Wildlife and Economic Development.

https://www.enr.gov.nt.ca/sites/enr/files/file_reports/ estimation_of_herd_size_for_the_migratory_dolphin_and union_caribou_herd_suring_the_rut.pdf

Pedersen, C., Otokiak, M., Koonoo, I., Milton, J., Maktar, E., Anaviapik, A., Milton, M., et al. 2020. ScIQ: An invitation and recommendations to combine science and Inuit Qaujimajatuqangit for meaningful engagement of Inuit communities in research. Arctic Science 6(3):326-339. https://doi.org/10.1139/as-2020-0015

Poole, K.G., Gunn, A., Patterson, B.R., and Dumond, M. 2010. Sea ice and migration of the Dolphin and Union caribou herd in the Canadian Arctic: An uncertain future. Arctic 63(4):414-428. https://doi.org/10.14430/arctic3331

Roberto-Charron, A. 2020. Dolphin and Union management consultation: Consultation on 2018 survey results and interim total allowable harvest. Summary report. Kugluktuk: Government of Nunavut, Department of Environment.

https://www.nwmb.com/en/public-hearings-a-meetings/ meetings/regular-meetings/2020-1/rm-004-2020 december-2-2020/english-13/8405-tab2c-gn-consultationsummary-dolphin-and-union-consultation-summary-reporteng-only/file

Robertson, J.B. 2017. From felt tip to technology: The challenges of representing traditional knowledge in a GIS platform to create a knowledge surface. MSc thesis, Ryerson University, Toronto, Ontario.

Saldaña, J. 2013. The coding manual for qualitative researchers, 2nd ed. Los Angeles: SAGE Publications.

Salomon, A.K., Quinlan, A.E., Pang, G.H., Okamoto, D.K., and Vazquez-Vera, L. 2019. Measuring social-ecological resilience reveals opportunities for transforming environmental governance. Ecology and Society 24(3): 16. https://doi.org/10.5751/ES-11044-240316

SARC (Species at Risk Committee). 2013. Species status report: Dolphin and Union caribou (Rangifer tarandus groenlandicus $\mathrm{x}$ pearyi) in the Northwest Territories. Yellowknife, Northwest Territories: SARC.

https://www.nwtspeciesatrisk.ca/sites/enr-species-at-risk/files/ dolphin_and_union_caribou_status_and_assessment_2013. pdf

Statistics Canada. 2016a. Population and dwelling counts, for census divisions, census subdivisions (municipalities) and designated places, 2001 and 1996 censuses - 100\% data for Cambridge Bay, HAM. 
2016b. Population and dwelling counts, for census divisions, census subdivisions (municipalities) and designated places, 2001 and 1996 censuses - 100\% data for Kugluktuk, HAM.

Tagalik, S. 2012. Inuit qaujimajatuqangit: The role of Indigenous knowledge in supporting wellness in Inuit communities in Nunavut. Prince George, British Columbia: National Collaborating Centre for Aboriginal Health.

http://www.ccnsa-nccah.ca/docs/health/FS-InuitQaujimajatuq angitWellnessNunavut-Tagalik-EN.pdf

Tester, F., and Irniq, P. 2008. Inuit qaujimajatuqangit: Social history, politics and the practice of resistance. Arctic 61(Suppl. 1):48-61. https://doi.org/10.14430/arctic101

Thompson, L.M., Klütsch, C.F.C., Manseau, M., and Wilson, P.J. 2019. Spatial differences in genetic diversity and northward migration suggest genetic erosion along the boreal caribou southern range limit and continued range retraction. Ecology and Evolution 9(12):7030-7046. https://doi.org/10.1002/ece3.5269

Thorpe Consulting Services. 2014. The caribou is the boss of the mine: Izok corridor project caribou Inuit Qaujimajatuqangit report. Results from interviews and a workshop carried out in Qurluqtuq (Kugluktuk) in 2012. Prepared by N. Thorpe and K. Scott with contributions from M. Kakkianiun and G. Angulalik for MMG Ltd. Vancouver: Thorpe Consulting Services.

Thorpe, N., Hakongak, N., Eyegetok, S., and the Kitikmeot Elders. 2001. Thunder on the tundra: Inuit qaujimajatuqangit of the Bathurst caribou. Ikaluktuuttiak: Tuktu and Nogak Project.

Tilley, S.A. 2016. Doing respectful research: Power, privilege and passion. Black Point, Nova Scotia: Fernwood Publishing.

Tomaselli, M., Gerlach, S.C., Kutz, S.J., Checkley, S.L., and the Community of Iqaluktutiaq. 2018a. Iqaluktutiaq voices: Local perspectives about the importance of muskoxen, contemporary and traditional use and practices. Arctic 71(1):1-14.

https://doi.org/10.14430/arctic4697
Tomaselli, M., Kutz, S., Gerlach, C., and Checkley, S. 2018b. Local knowledge to enhance wildlife population health surveillance: Conserving muskoxen and caribou in the Canadian Arctic. Biological Conservation 217:337-348. https://doi.org/10.1016/j.biocon.2017.11.010

Tomasini, S. 2018. Unpacking the Red List: Use (and misuse?) of expertise, knowledge, and power. Conservation \& Society 16(4):505-517. https://doi.org/10.4103/cs.cs_16_52

Tryland, M., and Kutz, S.J., eds. 2019. Reindeer and caribou: Health and disease: Boca Raton, Florida: CRC Press, Taylor \& Francis Group. https://doi.org/10.1201/9780429489617

Wheeler, H.C., Danielsen, F., Fidel, M., Hausner, V., Horstkotte, T., Johnson, N., Lee, O., et al. 2020. The need for transformative changes in the use of Indigenous knowledge along with science for environmental decision-making in the Arctic. People and Nature 2(3):544-556. https://doi.org/10.1002/pan3.10131

White, G. 2006. Cultures in collision: Traditional knowledge and Euro-Canadian governance processes in northern land-claim boards. Arctic 59(4):401-414.

https://doi.org/10.14430/arctic289

Wilson, N.J. 2019. “Seeing water like a state?”: Indigenous water governance through Yukon First Nation self-government agreements. Geoforum 104:101-113. https://doi.org/10.1016/j.geoforum.2019.05.003

Wong, C., Ballegooyen, K., Ignace, L., Johnson, M.J., and Swanson, H. 2020. Towards reconciliation: 10 calls to action to natural scientists working in Canada. FACETS 5:769-783. https://doi.org/10.1139/facets-2020-0005

Wray, K., and Parlee, B. 2013. Ways we respect caribou: Teetł'it Gwich'in rules. Arctic 66(1):68-78. https://doi.org/10.14430/arctic4267 